University of Nebraska - Lincoln

DigitalCommons@University of Nebraska - Lincoln

Papers from the University Studies series (The University of Nebraska)

October 1905

Studies on Human Parasites in North America: I. Filaria loa

Henry B. Ward

University of Nebraska

Follow this and additional works at: https://digitalcommons.unl.edu/univstudiespapers

Part of the Life Sciences Commons

Ward, Henry B., "Studies on Human Parasites in North America: I. Filaria loa" (1905). Papers from the University Studies series (The University of Nebraska). 2.

https://digitalcommons.unl.edu/univstudiespapers/2

This Article is brought to you for free and open access by the University Studies of the University of Nebraska at DigitalCommons@University of Nebraska - Lincoln. It has been accepted for inclusion in Papers from the University Studies series (The University of Nebraska) by an authorized administrator of DigitalCommons@University of Nebraska - Lincoln. 


\section{UNIVERSITY STUDIES}

VoL. V

OCTOBER $\quad$ I905

No. 4

I.-Studies on Human Parasites in North America

I. Filaria loa

BY HENRY B. WARD

CONTENTS

I. Introduction

Origin and scope of paper. $\quad . \quad \cdot \quad . \quad . \quad . \quad 2$

Data on new cases in North America . . . . . 3

2. Cases of Filaria loa on record

List of genuine cases . . . . . . . . II

Cases wrongly assigned to Filaria loa . . . . $\quad 22$

3 Morphology of Filaria loa

Structure of the parasite . : . . . . . 26

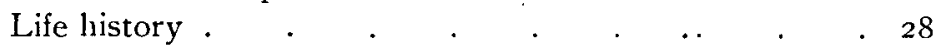

Taxonomy . . . . . . . . . . 3 I

Geographical distribution . . . . . . . $\quad .33$

4. Pathology of Filaria loa

Seat of the parasite . . . . . . . . 38

Effects on the host . . . . . . . . 40

Calabar swellings $. \quad . \quad \ldots \quad . \quad . \quad . \quad . \quad .4 \mathrm{I}$

5. Clinical data

Case of Milroy . $\quad . \quad$. $\quad . \quad . \quad . \quad . \quad 46$

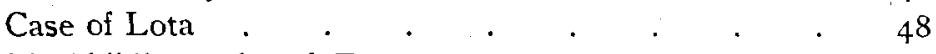

6. Critical bibliography of Filaria loa

Annotated list of references . . . . . . 50

UNIVERSITY Studies, Vol. V, No. 4, October 1905. 
In February, 1902, Dr. W. F. Milroy, of Omaha, brought me a specimen in alcohol which he had just removed from the eye of a patient and which he believed to belong to the rare and interesting African species, Filaria loa. He expressed a desire that I make a more precise examination of the specimen and that our results be included in a joint communication. The study of this specimen demonstrated that it was in fact Filaria loa and disclosed some interesting features in the anatomy which, together with Dr. Milroy's clinical observations, were presented before the American Association for the Advancement of Science in 1902. Circumstances have delayed the appearance of the final paper beyond all expectation, and meantime a contribution by Looss (I904) has dealt with the anatomy of this species so fully as to cover all the points I had worked out. Indeed the admirable work of this author sets the 11 mits for anatomical studies for many years to come. Accordingly, the part of this contribution dealing with the anatomy has been reduced to a brief summary.

Since this preliminary contribution, I have been fortunate enough to secure the data on several other cases in the United States which have not yet been published, and have had an opportunity to study six other specimens which have been sent me for that purpose. To all the gentiemen who have contributed so generously of their material and have cooperated so unselfishly in securing data on this interesting parasite, I desire to return here my sincere thanks. For these cases I have given the description largely in the precise words of the observer to whom I am indebted for the record. The more extended notes of Dr. Milroy are included in a separate section of this paper.

Through the courtesy of Dr. B. C. Loveland, formerly of Clifton Springs, but now of Syracuse, New York, I am able to give the following account of several interesting cases. In two he removed the parasites himself and one of these, that taken

- from the eye of Mrs. J., I have been privileged to study this summer. Of the iclentity of this specimen there can be no doubt, and in the other case the evidence is strongly in favor of its interpretation also as $F$. loa. The location and date lead me to 
identify the case of Mrs. R. with the one reported by Wilson in $I 890$ and enrolled as case $3^{I}$ in my list below. If so, three other specimens were removed from the same host and all these three from the eyelids : additional evidence in favor of assigning this form to $F$. loa. Regarding these cases Dr. Loveland writes as follows:

"About I 890 Mrs. R. was under my care and told me that she was the possessor of one of those worms which would make its appearance at times in the eye and at times come up close under the skin in some other region, where it would produce a sensation of stinging or irritation. I told her to call me at once when it should appear, as she said that it would disappear very quickly into the deeper tissues. She came to my office one evening and told me her worm had come to the surface on her back. And on inspection it appeared not far from the lower angle of her left shoulder blade, where it gave the appearance of a thread drawn in rather crookedly just as close as possible to the cuticle, where it could be felt as well as seen.

"I made a quick incision parallel to it in the midlle, and grasping it with a pair of small forceps slowly withllew it at it let go,' so to speak. It was of the type of nematode or round worm, about one and one-half or possibly two inches in length when stretched out, but contracted to much shorter. I had the misfortune to lose it while I was away on a vacation some months later-I think it was a Loa.

"In I898, while still at Clifton, Dr. Spaulding called me into his office to see something in the eye of Mrs. J., an African missionary patient of his, the like of which he had never seen. I recognized what $I$ thought to be the same worm and secured it at once. This worm I have to-day mailed you; it was, so far as I could tell, the same as the one I removed from the back of Mrs. $\mathrm{R}$. in 1890 .

"She [Mrs. J.] says they are quite common in that part of Africa, Batanga, West Africa, where she was stationed.

"She says that her husband and children have all had them. She also says that the worms make sores on the hands or feet and are sometimes captured at those times and places. It is only 
occasionally that they produce a sore or abscess, and I think that is when, like the Guinea worm, they lay their eggs [embryos] or multiply in a given locality. This last is only hearsay.

"These cases came under my care inciclentally and have never been reported."

From Dr. C. F. Friend, of Chicago, formerly a medical missionary of the Presbyterian Church in West Africa, I have been the recipient of most courteous information regarding a case hitherto unreported. Dr. Friend very kindly sent me the specimen in alcohol together with photomicrographs he made from the living worm, and also drawings of the specimen. There is no doubt as to the species, which is unquestionably $F$. loa. Regarding this case Dr. Friend says:

"This is the only specimen that I have ever removed, and it is that from Mrs. X.'s eye about four years after her return to America. I am sorry to say that I have lost or misplaced the notes made at that time or I would send them with this letter.

"While I have not removed a Loa from any part of the body other than the eye, yet I have thought that it did travel to other parts, for at different times both Mrs. X. and myself have seen what appeared to be the movement of the worm in different regions of her body. And I have thought that swellings which appear at times on her hands or arm and a time or two on her thigh were caused by the. Loa, as she would have the sensation as of the movement of the worm prior to the swelling, but not always so. In fact, at times when we thought we saw the worm in the parts referred to there would be no swelling, and again when I have cut down upon the part when we thought we saw it, we did not find the Loa. On the other hand, I think Dr. Loveland did remove a Loa from under the skin of the back of Mrs. $R$. about 1890 . The specimen I am sending you was removed early one morning from under the conjunctiva of the left eye near the outer canthus.

"The night before Mrs. X. had complained of a sharp, piercing, pricking sensation, or pain in the eye, which from previous experience she knew to be the movement of the worm, but I could 
see nothing of it. Upon arising, she could see the worm moving across the eye downward and inward. Mrs. X. thinks that the worm when it appeared in the eye would nearly always, if not always, go out by way of the inner canthus.

"As quickly as possible I prepared the instruments, cocained the eye, and with a small pair of locked forceps grasped the worm and the tisstes around it. This pair of forceps was then held by an assistant. I then took a lancet and cut down upon the worm, and with another pair of forceps grasped it, and after unlocking the other forceps pulled it out, when it wiggled much the same as an earthworm would do under similar circumstances.

"One peculiarity that I may mention regarding the action of the worm in this case is that at no time during pregnancy did Mrs. X. feel any movements of the worm. This was noted in two pregnancies prior to the removal of the worm I am sending you and in two pregnancies in regard to the worm yet in her system.

"When cut from the eye the Loa measured $3^{2} \mathrm{~mm}$. in length."

Through the brief mention of these cases made by Primrose ( I903:I264) I became aware of two observations in Toronto that probably concerned $F$. loa. As no account of these cases has been published as yet I am glad to be able, through the courtesy of the two gentlemen, to present here the record of the same. It was more than ten years ago that Dr. F. N. G. Starr showed at a meeting of the Toronto Pathological Society a specimen of a filaria he had removed from a patient. The worm was not placed at the time, but subsequent publications on $F$. loa showed its close resemblance to that species, if, indeed, it is not identical with it, as I believe. Since the specimen was lost, final evidence can not be secured. Concerning the case Dr. Starr writes as follows:

"The patient, a female, and about thirty-five years of age, had been for some years a missionary on the West Coast of Africa, and because of broken-down health, caused by a series of attacks of fever, she returned. On her way here she had a worm 
removed. ${ }^{1}$ She presented herself to me with the following story: That at times she would begin to feel an uncomfortable suspicion of burning and fulness in some part of the body, and that after a time she could see something crawling under the skin. This would last a few minutes, and then the part where it approached the surface would swell up, be sore for a day or two, and disappear, the amount of swelling depending a good deal upon the location. For example, if near the eyelids there would be very marked swelling. Several times she came to my office, but by the time she reached there the worm had disappeared, and I began to think the life on the West Coast had affected her brain. However, at last she came and I saw the movement under the skin for myself.

"The appearance was of a thin, white line, drawing itself up, and then projecting one end forward like the movement of a 'caterpillar'; presently the forward end would begin to disappear, and finally the whole 'streak' would disappear from view. The next time I cut for it, but did so about its middle, and before I could pick up a pair of forceps to grasp it, the worm was out of sight. I then prepared a very sharp scalpel and a pair of fine pointed tissue forceps, and kept them in readiness, and after repeated attempts the patient came in. This time the filaria was crawling under the skin of the chest over the manubrium sterni. I cut the skin just behind the forward extremity and made a 'grasp' into the incision, when the patient assured me I had hold of it for she could feel it squirm. I pulled very cautiously, and a thread-like structure came out nearly two inches long, and about the size, I should say, of a No. r0 catgut suture material. There was never any recurrence of the trouble."

The second case in Canada occurred in the practice of Dr. Frederick Fenton of Toronto. He removed two specimens at different times from the eyelids of a patient. The specimens were identified as $F$. loa, and although the extended mss. record of the microscopical examination made at the time, which Dr.

1 This specimen, of which I have been unable to get further information, was also removed in Canada. 
Fenton was good enough to send for my use, gives nothing which absolutely confirms the diagnosis so far as the species is concerned, yet the details conform fully with $F$. loa, and the mention of such items as the well-known cuticular bosses makes the case reasonably certain. Both specimens were lost. The first and larger specimen, of which accurate measurements were made, was $55 \mathrm{~mm}$. long and $0.5 \mathrm{~mm}$. in diameter; the other was only $45 \mathrm{~mm}$. long. The following data regarding the case are taken directly from correspondence from Dr. Fenton:

"Mrs. M., aet. 48, was an educated and refined woman, the wife of a missionary. Prior to $\mathbf{1} 897$ she had resided for several years at Batanga, seventy miles inland on the Gaboon river. She first noticed trouble after returning to England in March, I897. One arm and wrist became greatly swollen and remained so for several months, causing considerable inconvenience owing to degree of swelling, but little if any pain. On subsidence of the swelling, the part remained 'black and blue' for a long time. At times she suffers from fever, pains in back, and general malaise; there were occasional lancinating pains, as if the worm were cutting its way through the tissues.

"I saw her in September, I898, with Dr. J. L. Davison, who had tried to remove one and failed from want of assistance. The outline of the worm could be plainly seen, lying beneath the skin of the upper eyelid. If touched, and at times when not irritated, it would wiggle through the tissues like a snake. The skin of the lid including the worm was grasped firmly with a pair of dissecting forceps and an incision made transversely, when the worm was seen lying at the bottom of the wound, looking like a fiddle string or a piece of silkworm gut, and was easily picked up and pulled out with a pair of forceps. It rapidly became stiff and hard after removal and was found to be $55 \mathrm{~mm}$. long and $0.5 \mathrm{~mm}$. in diameter, one extremity ending in a hook-like process, while the other is simply rounded off without any apparent thickening. In December of the same year I removed another, 45 $\mathrm{mm}$. in length, from the lower lid, and in the spring of I899 failed in an attempt to secure another. 
"On one occasion the worm lay açross the center" of the field of vision of her left eye for some time, though a careful examination failed to discover it on the anterior sturface of the eye; at that time the worm moved with the movements of the eye, being apparently within the eyeball itself. No ophthalmoscopic examination was made, so there was only the patient's history of the occurrence to suggest the penetration of the eyeball.

"These specimens were shown before the Toronto Pathological Society, and a brief history given, but no paper has been published concerning them. I saw this patient again in May, I899, and up to that time she had had no further trouble."

The largest group of specimens I was privileged to examine came to me through the courtesy of Dr. J. H. Murphy and Dr. D. T. Vail of Cincinnati, Ohio. In adclition to several fragments belonging probably to two worms, there were two perfect specimens of a female $F$. loa in alcohol and one specimen in balsam, probably entire, although both ends of the latter worm, were badly mutilated or shrunken in mounting and so imperfectly cleared that it was impossible to determine the sex or the character of these parts of the body. The cuticular bosses, whicin were so well described and figured by Blanchard (I899) for $F$. loa, are distinctly visible, and the general appearance of the body, in comparison with other unmistakable specimens of $F$. loa, leaves little doubt that this worm belongs to the species under consideration. The precise determination of this specimen is all the more important since it is the one removed by Dr. L. from his wife's breast. He extracted one of these worms fron the skin overlying the sterno-cleido-mastoid muscle and another from her left breast. One entire specimen in alcohol bears his name also on the label and is no cloubt the other worm noted. It is a perfect specimen of a female $F$. loa. I think this is the first instance in which a supposed $F$. loa removed in life from any other part of the body than the vicinity of the eye has fallen into the hands of a helminthologist for careful examination and determination. In view of the very large number of Filariac already reported from Africa, even though the fauna is necessarily most imperfectly known, the reports of the extraction of 
a Loa from other parts of the body than the eye have been received with some caution by helminthologists. This is clearly shown by the silence of Manson, Blanchard, and other authorities on this point, even though they cite in connection with some cases in the eye the popular opinion that such worms occur elsewhere in the body. In the present case we have the best of evidence, since the specimens in question were removed by a medical man, and on account of the importance of the matter I have. subjected them to most careful scrutiny. While one is not in sufficiently good condition to render an absolute decision possible, there can be no doubt as to the systematic position of the other specimen. Accordingly, it may now be affirmed that the $F$. loa does make its appearance near the surface in other parts of the bocly than the eye. Since Dr. Vail has in preparation a paper to be read before the American Academy of Ophthalmology and Oto-laryngology at Buffalo in September, 1905, I forbear to trench further upon his field and refer to his paper for further details regarding these cases and for a discussion of the clinical factors.

\section{Cases of Filaria loa on Record}

Many authors have assembled the earlier records of this parasite, but in general the lists given have been inaccurate and imperfect. The series given by Blanchard (r899) is admirable in manner of treatment and is the most complete. It includes twenty-five previous cases and one new one. The method employed of listing all records quoted from a given paper as one case under the name of the author seems to me undesirable since it does not clistinguish between the account of a single chance specimen and more extended observation. Here each case inclucles the history of only a single host, so far as this could be fixed, even though two or more parasites were removed from the one individual. If this method be criticised as incomplete, one can only reply that it is impossible to determine whether the multiple infection took place at a single time or through repeated introduction of the parasite. Only the positive demonstration of the latter condition would justify the interpretation of the nu- 
merous parasites as separate cases of the disease. I have departed from this rule twice where the time interval was such as to justify the acceptance of the later record as a new case. So far as possible each case record includes the name, date, and place of observation, the sex, age, and nationality of the person infected, the number and sex of the worms, a statement regarding their removal, if accomplished, and the probable place and time of infection, and finally the place and date of publication. In some cases only a limited amount of data are given by the original recorder, and in many instances certain of these desiderata are lacking.

By no means all of the cases of which we have reasonably good information are included in the list, since some of the records, though distinct, are not definite enough to enumerate exactly in such a series. Thus Guyot (I805) speaks of several other individuals, on the coast of Angola; Wilson's patient says (Wilson, I 890 ) the disease is common among natives, and all the missionaries of that station, Benita near Gaboon, have them; Robertson's patient had seen such cases in the eyes of natives; Roth (I896) says his patieni informed him that a number of people in her village complained of the same disease; while Miss Kingsley, the well-known African traveler, speaks of these filariae as abundant and fairly common in different regions on the West Coast of Africa. Such evidence might be multiplied concerning this part of the world.

Not all cases are equally clearly established. I have followed the general custom of previous authors in including cases in which the identity of the parasite has not been finally demonstrated. Indeed, were one to demand precise identification all the earlier cases and many of the later ones must be thrown out. Again, other species have been reported from the eye of man and some of those doubtfully attributed to $F$. loa in this list may belong to such species. In such cases the geographical location of the case or the past record of the infected person are of importance in determining the probable species of Filaria represented. Even thus no case has been included in this list except the weight of evidence was strongly in favor of the interpreta- 
tion given. Under this treatment the total number listed becomes ninety-four, from the record of Mongin published in 1770 to those of the current year (1905), a time interval of 135 years. About two-thirds fall within the last twenty years, and half the total number have been published within the ten years from 1896 to date.

The matter of the earliest record calls for a word of comment. Pigafetta (I525) has been cited by Guyon ( I864), Manson, Moniez ( 1896 ), and Blanchard (1886, I899) as evidence of the occurrence of Filaria loa in Africa in the sixteenth century. 'This claim is based upon a plate, one figure of which is interpreted by these authors as illustrating the removal of an eye worm. It appears that this plate does not belong to Pigafetta's works, but to Lindschoten's; and even here it is not found in the original edition ( 1596 ), but occurs first in the De Bry reprint where it was probably inserted by the publisher. I have discussed the matter in detail elsewhere (Ward, I905). The region describeci by Lindschoten lies in the Persian Gulf, and not in the Congo territory, where Guyon et alii located the account. It is thus well within the range of Dracunculus medinensis, but far removed from the habitat of Filaria loa. Furthermore the text makes no mention of infected eyes, but speaks of "worms in the legs" of the natives, which again accords with the Guinea worm. Hence the interpretation placed upon the plate must be rejected, and if, indeed, the plate itself has any standing as evidence, it concerns the Guinea worm rather than Filaria loa. This reference must accordingly be eliminated from discussions of the latter species. It is not listed here among the cases of $F$. loa which I have collected, verified, and arranged as follows:

I. Mongin at St. Domingo in I770 records the extraction of one worm from between the conjunctiva and albuginea of $\lambda$ negress.

2. Bajon at Cayenne in 1768 removed a worm from below the conjunctiva of a negress eight years old; this case was first published in 1777 together with the following. 
3. Also at Cayenne in 177 I Bajon observed in an older.negress such a worm moving across the eye between conjunctiva and cornea, but was not allowed to remove it.

4. Mercier at St. Domingo in I77I extracted a worm from beneath the cornea of a negress.

5. The same authority in 1774 removed from a negro a worm which lay above the cornea. The record of cases 4 and 5 was published by Arrachart in 1805 .

6. Arrachart notes that in 1795 Mlle. L. Fraise, creole, born in St. Domingo, assured him that her brother had several times such worms in his eyes at the age of three to five years; they were successfully extracted. She also adds that young negroes were often attacked. This striking note seems to have been overlooked by students of the subject. The direct implication that the child was born in St. Domingo would indicate the existence there at that time of a center of infection for $F$. loa, such as is known to have existed for the Guinea worm (Dracunculus medinensis) at several points in the Western Hemisphere during the continuance of the slave trade. The alternative that some other species was involved seems less acceptable as there are no other records favoring this view, unless the South American cases indicate the rare occurrence there of a native species similar in habit to $F$. loa.

7. The French naval surgeon, Guyot, made several voyages to the coast of Angola. On one occasion, examining closely the eye of a negress, he saw what seemed to be a varicose vein in the conjunctiva, but when he touched it with the point of a lancet the object disappeared. It appeared several times in the same patient at irregular intervals, and he thought that between times the worm retired to the posterior region of the orbit. $\mathrm{He}$ recorded the native name of $L o a$, the common occurrence of the malady, the irregular appearances of the worm in the eye, and the inefficacy of all medication. The case was first published in Arrachart, 1805 .

8-12. In 1777 Guyot made a new voyage to the coast of Angola. He observed again this verminous ophthalmia among the negroes of the Congo, and in two cases out of five succeeded in 
removing the worms. The account of these cases was first published by Arrachart ( $1805: 228$, observations $7 \mathrm{ff}$.) and later by Rayer (1843). Guyot was the first to view this species as different from the Guinea worm. He says: "Je ne crois pas que ces vers soient de l'espèce du dragoneau, car ils sont trés blancs, plus dur et mois longs à proportion. Je ne jamais vu ce ver se faire jour de lui-même. Pendant sept voyages que j'ai fait à la côte cl'Angôla, je n'ai vu aucun nègre attaqué du dragoneau. Plusiers chirurgiens qui ont navigué sur ces côtes m'ont assuré n'en avoir jamais vu."

I3. M. de Lassus, army health officer of St. Domingo, removed a worm from the eye of a negro. The case is chronicled by Larry, 1812 .

14. In 1828 a worm was seen in the orbit of a negress, recently arrived as a slave from Africa at Monpox, a village on the banks of the Magdalena river in United States of Columbia. This observation is attributed unmistakably by the original text to Clot-Bey, a French surgeon, well known for his work in Egypt about that date. The French authors agree in pronouncing this authorship an error and in substituting the name of Roulin. I have found neither explanation nor reference to Roulin or his works.

I5. Dr. Blot, a physician on Martinique, in I837 removed two filariae from the eye of a young negress who had come from the African Coast. One was sent to Guyon and Blainville, and described by the former (Guyon, 1838 ).

16-17. Loney, an English naval surgeon, in April and June, i842, extracted moving worms from beneath the conjunctiva of two Kroomen on the West Coast of Africa. He reported these cases together in 1844 .

I8. Lallemant excised a worm from the eye of a negro in Rio de Janeiro, and in 1844 published a description of the case.

19. In I833 Christovó José dos Santos removed a worm from the orbit of a Mina negress. Sigaud witnessed the operation and reported it in 1844 .

20. Lestrille in 1854 removed a worm from the eye of a negro at Gaboon; his description of the case was published by Gervais et Van Beneden ( 1859 ). 
21. Mitchell saw such a worm in 1845 at Trinidad. The host, a young negress, had come from the West Coast of Africa in I834; the worm made its first appearance in the left eye in 1837 , again in $184 \mathrm{I}$. The specimen Mitchell saw was presumably att least eleven years old, although he infers wrongly that the various reports necessarily concern the same individual parasite. According to tradition one had been seen in a family in Antigua sixty years before. Mitchell reported his case in 1859 .

22. In 1864 Guyon reported another specimen removed by a marine surgeon from a negro in Gaboon. Part of this worm remained entangled in the deeper tissues of the orbit.

23. In March, I868, Dr. Maurel at Gaboon removed a worm from the eye of a native. Trucy (I873) reported the case as Observation III, in a paper on the Guinea worm.

24. Rev. Dr. Nassau, a missionary in Gaboon, sent in 1876 10 Dr. Morton, a surgeon in Philadelphia, a Loa taken from the eye of a native woman. The worm was examined by Leidy, whose brief description and the account of Dr. Nassau, which also includes cases 25 and 26, were published by Morton (1877).

25. Rev. Dr. Nassau records that while he has never had the worm in his eye, he has yet seen it moving beneath the skin of his fingers. In Gaboon the worm shows itself at various points of the body of the host, in the fingers and eyelids as well as under the conjunctiva. He has seen the worms both in his own fingers and in those of other persons. The effort to extract one specimen from his eyelid failed by virtue of the activity of the worm. Though evidently incomplete, this observation furnishes the first suggestion that the parasite is not exclusively confined to the region of the eyes.

26. An English trader, Captain Stone, living on the Ogoone, had one removed from his eye by a native using a thorn as a needle. The case is quoted from a letter by Dr. Nassau in Morton, 1877.

27. Dr. Bachelor of Gaboon extracted a specimen from the eye of a native young man. It was on the iris beneath the sclera. This was the first perfect specimen sent to the United States. The case is reported in his letter (Bachelor, I880). 
28. Dr. Bachelor reported a year later (I88I) the case of a white woman, a missionary near Gaboon, from whom at different times three such worms were removed. He also confirms the record (case 25) that Dr. Nassau, who was frequently affected, "had one in the areolar tissue between the thumb and index finger."

29. Dr. Falkenstein sent Leuckart from the Loango coast a specimen of this worm from the eye of a European, which was determined and reported as a species clearly distinct from the Guinea worm (Leuckart, I88r).

30. Dr. Lota, a French physician in Gaboon, experienced conjunctivitis after his return to France, and on careful examination saw such a worm beneath the conjunctiva. He noted its movements and demonstrated the case to. several colleagues; but the worm disappeared before removal. His eyesight was not impaired. The case is chronicled by Terrin, 1884 .

31. Mrs. - missionary at Benita, near Gaboon, had at intervals felt. and seen such worms. She had one removed in February, I889, at Basel, Switzerland, from the left upper eyelid, one in November, I889, at Bridgeport, Conn., from the right upper eyelid; one in February, I890, at Clifton Springs, N. Y.. from beneath the skin of the back; and in July, I890, one broke in removing it from the right upper eyelid. She says the worm is common in Benita and all the natives have them, and the author adds: "So far as I have been able to obtain evidence from the missionaries themselves, the filariae are more common in the cellular tissue than in the eyeball. From the literature we should infer the opposite." The worm was removed and the case reported in $\mathrm{I} 890$ by Dr. F. M. Wilson of Bridgeport, Conn.

32. One other missionary at Benita had such worms removed. The fact is chronicled by Wilson ( 1890 ) on the direct testimony of his patient of case $3 \mathrm{I}$.

33. An infant negress from the Congo had a worm in the anterior chamber of the eye. It was reported by Coppez (1894), van Duyse (I895), Gauthier (I895), and Lacompte (I894). When extracted by the latter it was dead.

34. An English woman who had lived eight years in Old Calabar felt the parasite a month after her return to England, but 285 
later thought it had disappeared, as one was passed per rectum. Eight months after her return a male was removed from one eye by Dr. Robertson and reported by him (1894, I895). From the same patient he removed subsequently (1895:162) a female worm. Further history of this patient is recorded in case 73 .

35. A woman who lived at Old Calabar from 1860 to 1863 had suffered while there from a worm in the eye. After her return she had a Loa removed in 1875 and a second in 1876 . The case is recorded by Robertson ( 1894,1895 ).

36-37. Dr. Thompstone, of Opobo in Nigeria, described two cases of Loa in natives. One was. in the lower eyelid, the other beneath the conjunctiva. He was not able to remove either worm. These data were published by Robertson (I894, I895):

38 . In a woman at the same mission with case 33 , the worm was seen to pass from one eye to the other over the bridge of the nose. It was not removed. The case is recorded' in Robertson ( 1895 ).

39. A missionary in Old Calabar had a Loa which showed itself at irregular intervals for about fifteen years and then disappeared without having been removed. Robertson (1895) gives the record of the case.

40. Dr. J. R. Logan, of Liverpool, removed a male Loa from the eyelid of a patient. The blood of this patient was examined for filariae but held none. This worm was examined and described by Manson (Robertson, I895). No further data are given.

4I. A female $F$. loa was taken by a merchant from the eye of a negro at Cayo (French Congo) and sent to Berlin. The case was recorded and discussed by Hirschberg ( 1895 ).

42. In I895 Dr. Saemisch extracted a Loa from the eye of a Russian marine officer who had been in Fernando Po from I886 to $189 \mathrm{I}$, and in Gaboon, Kamerun, and the Gold Coast from 1882 to 1885 . The parasite was carefully described by Ludwig (Ludwig und Saemisch, I895).

43. In July, i895, Roth observed an extremely active Loa in the eyelid and just above it in a Jackrie girl at Warri, on the coast of Nigeria. He failed in the effort to remove it. 
44-45. Later the same author (Roth, I896) observed similar worms in two other natives without being able to extract them. He believed they passed out through the nasal duct. In spite of their frequence a reward failed to secure specimens.

46. In I 893 Barrett removed a worm from the eye of a young white man who had lived on the Gold Coast but had left there four years before and since then had resided in Melbourne; it was the first specimen removed in Australia. The worm was examined by Professor Dendy and determined as Filaria oculi humani. Barrett reported the case in 1896.

47-49. In three natives of Kamerun Dr. Plehn observed specimens of Loa in the eye. He attributed to the worm also the variable cutaneous inflammations found on the West Coast of Africa, and cliscussed them at length (Plehn, I898).

50. In an English official .Plehn also knew of a case, although he did not see the worm himself. According to the natives this worm occurs also in the eye in goats and sheep. He records these facts in the paper cited above (Plehn, I898).

51. A French missionary who spent $1894-96$ on the Ogooue in French Congo was relieved of a male $F$. loa by Dr. Bernard in 1898 at Paris. Bernard clescribed the case (1898) and sent the specimen to Blanchard for study. This was in fact the seconil specimen taken from the same host; the first was described later (see case $5^{2}$ ).

52. Dr. Leneven removed a female Loa from the same host in August, 1897. The case is recorded by Blanchard (1899), who also gives an extended account of the anatomy of the two specimens.

53. Manson had a negro patient under his care in whose blood $F$. diurna abouncled. When a lad he had a Loa in his eye. The case is recorded in Manson, I893.

54. A lady long resident in Old Calabar had a Loa extracted from under the skin over the right clavicle. She informed Manson (cf. Manson, 1900:562) that if rubbing or scratching is not indulged in when a Loa approaches the surface there will be no swelling, and that Calabar swellings are produced by the rubbing solicited by the irritation caused by $F$. loa . 
55. Annett, Dutton, and Elliott (1901) record that at Bonney they were fortunate enough to obtain a single female of this species for their collection. Since nothing is said regarding host and location, it is fair to assume its removal from the usual place, the eye of man.

56. The same authors received a female parasite taken from the eye of a Kroo boy by Dr. A. H. Hanley, medical officer at Opobo. In the blood of the host were embryos most similar to Manson's $F$. diurna.

57. Dr. A. H. Hanley also sent a male $F$. loa from the eye of a Kroo boy whose blood had no embryos at all. This case is recorded by Annett, Dutton, and Elliott, I90r.

58. In 1902 Dr. Milroy removed from a man who had been a missionary in Batanga a male $F$. loa. It was first observed in I899. The case was first published by Ward (I902), but the full account by Dr. Milroy is found in this paper.

59. Dr. Rennes removed two specinens of $F$. loa from a European in Sierra Leone, where no previous case had been noted. The patient had been. living in the Congo and had been in Sherboro only one year. One worm was removed from the eyelid and the other from the loose skin of the penis. The blood of the patient was swarming with embryos. The case is recorded by Prout, 1902.

60-6r. Dr. Thompstone removed two males and two females from natives of Opobo, Nigeria, and sent them to Dr. Manson of London. They were described by Ozzard, 1903. No data are given regarding the hosts, but they were probably natives.

62-67. At the mission station of Yakusu near Stanley Falls, upper Congo river, Mr. S. S. found $F$. loa very common among natives. He saw at least six cases. The record was published by Manson, I903.

68. Dr. Frederick Fenton of Toronto, Canada, removed two worms from the eyelid of a patient in September and December, I 898 , and failed in 1899 in the effort to secure a third. The case was presented to the Toronto Pathological Society, but not published. It was noted briefly by Primrose (1903) and is published in full in the present paper (pp. 6-8). 
' 69. Dr. F. N. G. Starr of Toronto, Canada, removed a filaria, probably $F$. loa, from a female patient who had been a missionary on the West Coast of Africa and had returned to Canada on account of ill health. The worm was taken from the skin above the manubrium sterni. The specimen was shown at a meeting of the Toronto Pathological Society about ten years ago. The case was briefly noted by Primrose (1903) and its data appear in full in the present paper (p. 5). Dr. Starr's observations are apparently the first made by a physician on the movement of such a parasite in the body outside of the region of the eye.

70. Dr. Habershon ( I9O4) records from Yakusu, Congo river, that in Mr. K. S., afflicted with Calabar swellings, a Loa was seen to cross the conjunctiva.

7I. Dr. Habershon (I904) also adds that the same conditions were observed in a native.

72. Dr. D. Argyll Robertson says that his patient suffered from Calabar swcllings and noticed worms $(F, l o a)$ in her side, left shoulder, under the skin of both hands, under the abdominal wall, and in her right breast. The parasites were successfully extracted from the last two situations. The record was published in Habershon, I9O4.

73. Dr. Robertson also records the case of another English woman from Old Calabar in whom $F$. loa was seen under the conjunctiva while she herself noted them under the skin of hands, wrists, breast, face, and scalp. Four attempts to remove them , from under the skin of the nose, hand, and arm failed. He says further that there is no doubt that in many cases several worms are present in the same host. The record was published by Habershon, Ig04.

74. A young French girl who had stayed several years at Libreville (Congo) was taken in 1902 with painful localized edemas of both hands and wrists, occasionally of legs, associated with some rigidity and loss of power. A white worm about the size and length of an ordinary pin was seen beneath the ocular conjunctiva, reappearing later beneath the skin of the eyelids of both eyes, of both forearms, and finally under the frenum of the tongue. Attempts to remove the worm failed. She returned to. 
France in Ig03, and a Loa was extracted from the eye in January, 1904. An intense cosinophilia was noted in 1903, and though subject to fluctuations, continued after the removal of the worm. Probably other parasites also were present. The case is recorded by Wurtz et Clerc, 1904, 1905, and Kerr, 1904.

75. Rev. S. O. K., from Yakusu on Upper Congo, where he had been for three years, returned to England in January, 1904. Localized swellings, chiefly on the left forearm, first appeared after one year in Yakusu. Blood examinations showed microfilariae with diurnal periodicity well marked, hence diagnosed as $F$. diurna. The case was sent by Dr. Habershou to Sir Patrick Manson and described by Kerr (I904).

76: In a European who suffered from these transient swellings there was also a Filaria loa present and in the blood numerous embryo filariae which could not be distinguished from F. diurna. The case was observed by Dr. Hanley of Old Calabar and published by Kerr, I9O4.

77. From a native of Old Calabar a $F$. loa was renoved and found to be full of sheathed embryos indistinguishable from $F$. diurna, which were also found in the blood. No mention is made of swellings in this case by Dr. Hanley, whose account was published by Kerr, 1904 .

78. At an autopsy of a Congo negro who died in Paris of sleeping sickness, Penel (1904:207) found more than thirty adults scattered through the superficial connective tissue of the four appendages, and despite most careful search not a single specimen could be discovered in the neck, face, or region of the eye.

79. In 1904 Looss published an account of the structure of $F$. loa based on three specimens from the Gold Coast; their source is unknown. They represent at least one case of human infection with this parasite.

8o. At an autopsy of a native in Kassai, Brumpt found among other specimens encysted and so completely calcified as to be unrecognizable, a fragment of a Filaria encysted in the heart, which on return to France and comparison he identified as $F$. loa. It was a female and contained embryos identical with those in the blood of the same host. The case is recorded in Brumpt, I904. 
8I. A specimen $60 \mathrm{~mm}$. long was taken from beneath the conjunctiva of a man who had lived in Kamerun from 1897 to 1898 and since then in Germany. There was no intimation of the parasite until the day before removal. The case is recorded by Pick, I905.

82. Dr. Hans Ziemann records (1905) that he had in his earlier service one case of $F$, loa. The host was presumably a native and the locality probably the same as that given for the following record.

83-86. The same author records the occurrence of four cases in his later service. Apparently he was stationed at Duala, Kamerun.

\section{NEW CASES}

87. Mr. K. observed that on one occasion when a Calabar swelling upon the back of a woman's hand was rubbed, such a worm was seen to emerge from the tumefaction and make its way across the metacarpo-phalangeal articulation, from which location it was extracted. These data are recorded by Milroy in the present paper ( $\mathrm{p} .47$ ).

88. In 1890 Dr. B. C. Loveland removed a Loa from the skin above the lower angle of the left scapula of Mrs. R., formerly a missionary near Batanga, West Africa. Recorded in the present paper (p. 3).

89. In 1898 Dr. Loveland extracted a Loa from the eye of Mrs. J., also a returned missionary from Batanga, West Africa. The specimen I have described in ti:is paper (p. 26), and the case is recorded here also (p. 3 ).

90-92. On the evidence of Mrs. J., her husband and children have all had the same parasite. The fact is recorded by Dr. Loveland in this paper (p. 3 ).

93. Dr. C. F. Friend removed a Loa from the eye of Mrs. X., formerly a missionary in West Africa, about four years after her return to America. This specimen is described in this paper (p. 26) and the data on the case are also recorded herein (p. 4).

94. The case of Dr. D. T. Vail of Cincinnati, O., briefly referred to in the preceding pages (p. 8) and reported at length 
before the Buffalo meeting of the American Academy of Ophthalmology and Oto-laryngology.

\section{CASES WRONGLY ASSIGNED TO F. LOA}

It is no matter of conjecture that other species of filaria than $F$. loa do occur in the human eye. In Italy, for example, Addario ( 1885 ) observed in the eye of man a nematode which he named $F$. conjunctivae. Later Grassi ( 1887 ) published an extended description of the same form to which he gave the name of $F$. inermis. He also discussed the cases of its occurrence in man and showed it to be a normal parasite of the horse and ass that, as an erratic parasite, occurs at times in the human eye. In spite of a certain similarity in general character its differentiation from $F$. loa is not a matter of any difficulty in case a precise examination is made of the specimen in question. However, when no such examination is recorded, the area of geographical distribution becomes determinative in general, and cases with insufficient data occurring within the range of this or a similar species will be referred to it by preference rather than to $F$. loa. ${ }^{1}$ Thus the cases from Italy, in so far as they are not errors in observation, are naturally assigned to $F$. conjunctivae in the absence of more precise information as to the actual species concerned.

In similar fashion the case of Drake (1894) from Madras, India, is regarded by Blanchard as belonging most probably to F. equina, a common parasite of the horse and ass in that region and known in such hosts to make occasional incursions into the eye. The case of Neve ( 1895 ), also from India, in which the parasite was designated specifically as $F$. loa, appears to me to be undoubtedly an error in determination and to concern rather the species $F$. equina. I was unable to consult a copy of the paper by Macnamara ( 1863 ) which, to judge from the title, refers to cases also to be assigned to the species $F$. equina

${ }^{1}$ Reciprocally, it is just to assign to $F$. loa such cases as that of Maurel (Trucy, 1873). since the parasite was removed at Gaboon where the Loa is common. while it is beyond the range of the Guinea worm, to which the. case is referred by the author. 
( $=F$. papillosa) as occurring both in man and in the horse in India.

It is of great interest to note that in North America is found a species which occurs at times in the eye of the horse. Such cases are recorded for Canada by Sermon (1872) and for Pennsylvania by Turnbull (1878). In spite of the designation of the parasite in the first case as $F$. oculi, much used for $F$. loa by medical authorities, we are justified in attributing the case to some other species since the patient was a bay mare. Now the occurrence in this territory of a filaria in the eye of the horse - necessarily casts a shadow of doubt upon cases in man in which the supposed $F$. loa was not carefully examined since, as has been noted, species of similar habit in Italy and India occur at times also in the human eye. It is indeed altogether likely that cases will occur in this country in which the horse parasite will, as an erratic, invade the eye of man.

In view of these facts one would be justified in expressing doubt as to the correctness of certain cases generally listed with F. loa. In particular the cases of Lallemant (No. I8), and dos Santos (No. I9), from Brazil may justly be questioned. To be sure, both were originally regarded as cases of the Guinea worm, and only by later authors have they been interpreted as $F$. loa by virtue of their occurrence in the eye. While I am inclined to regard this habit as sufficient reason for rejecting the original determination, it should be confessed there is some ground for doubting the assignment of the worm to the species $F$. loa. The cases are unique in Brazil, and there is no evidence that the hosts, although of negro blood, were recent importations from Africa. Now while there attaches some doubt to all cases in which a positive determination of the specimen was not made, yet, when the history of the host shows recent importation from Africa, as in many of those reported from the West Indies, the uncertainty is very slight. When the case history is not so clear the possibility of a chance infection with some form indigenous to the region is not definitely excluded. In other words, should future study show the presence in Brazil of some species such as is $F$. conjunctivae in Italy, the cases so definitely assigned 
by previous authors to $F$. loa would necessarily be withdrawn from the list. That such species are found in Brazil one can not doubt in view of the investigations of Daniels on Carib Indians of British Guiana and of Magalhaes on various hosts in Brazil itself. That any of these species occur in the eye.I have not yet found on record.

Other cases referred to by some authors as $F$. loa or listed in probable connection with that species should be stricken from the list on other grounds. One of the most difficult to explain satisfactorily is the case of Barkan (1876). The patient, an Australian, was operated upon in San Francisco for an eye worm, and the specimen, which was submitted to Dr. H. Knapp ${ }^{1}$ of New York, was pronourced upon microscopical examination to be "Filaria medinensis." There was no evidence that the patient had ever been in any, region where either the species noted or $F$. loa, with which it might easily be confused, is endemic. Consequently I am inclined to believe that the form was an Australian filaria normally occurring in some other host, but in this case appearing in man as an erratic.

For various reasons noted in the bibliograply one is not justified in assigning to Filaria loa the cases of De Mets (1876), Kuhnt (I892), and Nordmann (I832). Although in all three cases nematodes were actually demonstrated, they are so tinlike $F$. loa that their distinctness from this species can hardly be questioned. Still less connection with $F$. loa have the cases of Eversbusch, Fano, Malgat, Piccirilli, Quadri, and Schöler. The specimens of Piccirilli were observed in the anterior chamber of the eye, the worm seen by Schöler was in the lens, the other objects were all located in the vitreous body. All of these cases agree in that the supposed filaria was observed living in the eye by means of the ophthalmoscope. Such evidence is exceedingly questionable; in most instances manifests its weakness on close examination of the record, and in one case at least (Fano). demonstrated its insufficiency by a second examination eight years

${ }^{1}$ Dr. Knapp kindly informs me that, at my request, he has made every effort to trace the specimen, and that he fears it has been destroyed. 
later than the original, which disclosed unly trivial changes in the position and character of the object. One may also infer that in one case at least (Eversbusch) the author became convinced of the insufficiency of his evidence, since only a brief preliminary communication has appeared and the extended report which was promised therein has not been published. . Subsequent authors have not hesitated to pronounce these observations erroneous and to maintain that in fact the authors mentioned had to do with cases of a persistent hyaloid artery in which this vessel exhibited a peculiar worm-like form, while the supposed twistings of the filaria were only the results of vascular pulsations or of movements in the vitreous humor. The explanation accords fully with the original records, as I can distinctly affirm after a careful study of them, and indeed elucidates certain points otherwise inexplicable, such as the statement of Fano ( 1868 ) that the head of the worm remained constantly fixed at a given point while the body turned and twisted about. Since I have been unable to trace the references to Chiralt and to SantosFernandez, it is impossible to say whether these cases of a filaria in the vitreous humor are to be explained on the same basis or whether a filaria was actually present.

Quite recently Nakaizumi (1903) has reported a case of a filaria in the vitreous humor which he regarded as an immature $F$. loa. This conclusion appears entirely inadmissible, even though one rejects the opposite extreme of interpreting this case like those just discussed as some abnormal structure belonging to the eye itself rather than as a filaria. The history of the case gives no evidence that the patient had ever been in a region where $F$. loa was endemic and consequently where an infection with this species could have taken place. Furthermore, no evidence is adduced to indicate the specific character of the filaria observed. If, then, one grants that the object actually was a worm belonging to the genus Filaria, it is certain that it could not have been $F$. loa, but was some species indigenous to northern Europe, and probably $F$. conjunctivae or $F$. equina. The habit of the patient, who is said to have enjoyed half-roasted horse flesh, may indicate an infection with a young $F$. equina. It is exceedingly unfortunate that the literature of science should 
be loaded down with stich incomplete observations, and these are entirely unnecessary when the observations are made at such a time and place as that in question, where accurate data regarding these species were easily obtainable.

For reasons given in extenso elsewhere (Wárd, 1905) and already noted in the present paper, we must reject the classic reference to Pigafetta, more correctly Lindschoten, as the eàrliest authority to record a case of $F$. loa.

\section{Morphology of Fillaria loa STRUCTURE OF THE PARASITE}

The appearance of the admirable account of Looss (I904) makes any extended consideration of this topic superfluous. Only those points are noted which are peculiar to the specimens of this paper.

In all I studied carefully three males, those removed by Drs. Friend, Loveland, and Milroy, and have examined two others, probably males of $F$. loa, sent me by Dr. Vail. I have had only one female, an alcoholic specimen removed by Dr. Lippert and sent me by Dr. Vail.

One male from Dr. Vail measured about $16 \mathrm{~mm}$. in length, though the shrunken condition of both ends makes this measurement only approximate; the other male of this collection was not complete. The male Loa in alcohol from Dr. Friend measured $25 \mathrm{~mm}$. in length, ${ }^{1}$ and the specimen from Dr. Loveland, which was mounted in balsam and appeared somewhat shrunken, was about $22 \mathrm{~mm}$. in length.

In no one of these males was the tip of the tail as straight as figured by Looss, but curved distinctly though only gradually. From my original notes on the specimen of Dr. Milroy I excerpt the following:

The specimen measured approximately $28 \mathrm{~mm}$. in length and in alcohol was of a clear brown color, with distinctly marked lateral lines. The slightly reflexed posterior end and projecting spicules showed it to be a male. A more careful examination of

${ }^{1}$ Dr. Friend gives the length of this specimen living as $32 \mathrm{~mm}$. 
this region disclosed the four pairs of large circumanal papillae characteristic of Filaria loa. One important feature was noted in this connection. These papillae do not constitute four bilateral pairs, but rather a left and a right series of four each, in which the individual papillae alternate with each other, those of the left side being the more anterior, while those on the right are more closely crowded together. The anterior papilla is also the largest in each series, and the size decreases regularly posteriad.

This asymmetrical arrangement originally described by Looss is not an abnormality in the specimen he studied, and I can confirm his view that it' is a general characteristic. At least it is actually present in the three males $I$ examined and will no doubt be found on more extended examination to be universal.

Posterior to these large papillae lie, first, a symmetrical pair of small papillae and then, almost at the tip of the body according to Looss, a minute pair, also symmetrically placed. The latter I was unable to find.

In the specimen received from Dr. Loveland, the spicules could be most clearly seen; their length was $104 \mu$ and $\mathrm{r} 80 \mu$, measurements which accord closely, with those given by Looss. Further than this my observations, though in some respects less complete, merely confirm the anatomical description given by Looss. It is important to call attention to the results of a comparison of measurements of $F$. loa given by various authors, and since only relatively few have given sufficient data for the determination of the sex of the parasites, the figures available are much more limited than the number of cases.

According to various records the measured length of the male is $22 \mathrm{~mm}$. (Blanchard), $23 \mathrm{~mm}$. (Looss), 25 to $30 \mathrm{~mm}$. (Manson), 30 and $35 \mathrm{~mm}$. (Ozzard), and 16,22 , and $25 \mathrm{~mm}$. (Ward). It is noteworthy that the female varies more widely: among the measurements given are $20 \mathrm{~mm}$. (Blanchard); $50 \mathrm{~mm}$. (Annett, Dutton, and Elliott), $52 \mathrm{~mm}$. (Looss), $27 \mathrm{~mm}$. (Lueckart), 4I $\mathrm{mm}$. (Ludwig), $32.5 \mathrm{~mm}$. (Manson), 50 and $55 \mathrm{~mm}$. (Ozzard). Blanchard notes that his specimen was still young, and yet even that of Looss was far from having attained the size of Maurel's specimen, which measured $70 \mathrm{~mm}$. and which from its extreme 
length we are justified in regarding as a female. The specimen reported by Brumpt ( 1904 ) measured $60 \mathrm{~mm}$. and yet it was only a part of a female, both head and tail being lacking. The specimens of the female taken from the eye are thus usually if not always only partly grown. ${ }^{1}$ How much they fall short of full size can only be determined by the records of specimens, taken from post-mortem examinations, which have settled down in deeper tissues and are found to be producing embryos.

LIFE HISTORY

Concerning the life history of Filaria loa only meager facts are at hand, and yet they are so clearly related that one may sketch the main course of development with great probability. Manson (1893) was the first to suggest that the blood-inhabiting embryo called $F$. diturna was the young form of this species. The agreement in the geographic distribution of the two forms, the certainty that in the infected region the embryonic stage of $F$. loa must be common, and the absence of any other microfilaria made the genetic connection of the two almost an established fact. Yet the negative results of blood examination in several cases which harbored $F$. loa, especially that of Robertson (1895) from which both male and female $F$. loa had been removed, served to cast doubt upon the view. Such doubt was distinctly unjustified since, as I have pointed out, the forms extracted from the eye have been consistently immature and may have been removed before the female has begun the production of embryos.

These conditions of probable'slow development and of immaturity when in the eye agree well with known facts from related species of Filaria in other animals. Thus F. equina, a common parasite of the horse and ass, which occurs at times in the eye of the host, is found there in the semi-adult form which is also an active migrant. F. labiato-papillosa of deer and cattle appears,

If the record of Guyon (1864) that his specimen was $15 \mathrm{~cm}$. long does not rest on an error in transcribing or printing, it represents a much larger and hence more nearly full grown female than any other yet recorded. Ludwig has already shown that this case in all probability concerns Filaria loa (cf. Ludwig und Saemisch, 1895:737). 
when immature, in the eye; and in a large number of cases, immature nematodes of unrecognized species, often belonging to the genus Filaria, have been removed from this organ.

The embryonic form circulating in the blood vessels must evidently be removed from the body of the primary host by some species of blood-sucking insect. Manson thought that by virtue of the appearance of these embryos in the peripheral circulation during the daytime some day-biting insect must be responsible for the transfer. He suggested the Mangrove fly, Chrysops dimidiatus v. d. Wulp., a common form in the region in question. These conclusions were attacked by Annett, Dutton, and Elliott (I9Or) without their being in position to furnish any very decisive evidence for the view they advance of the identity of $F$. diuma and $F$. nocturna. More recently Brumpt $h: s$ brought forward strong evidence in favor of Manson's view in that he has discovered embryos of $F$. diurna in the circulating blood and identical forms in an adult female $F$. loa from the same host. He noted also that the embryos were constantly present in the peripheral circulation, even though more abundant by day than by night. The effort to discover the intermediate host in a species of Glossina was unsuccessful. If the observation of Brumpt that embryos are constantly present in the peripheral circulation is confirmed, then it is evident that the intermediate host may be a mosquito, as in the case of other species of Filaria. Annett, Dutton, and Elliott found that Anopheles costalis served in West Africa as intermediate host for $F$. Bancrofti but not for $F$. diurna. This observation will not exclude other mosquitos also; however, it does speak strongly against their view of the identity of these two microfilariae.

Whatever may be the precise character of the intermediate host, of the changes passed through by the embryo filaria within it, and of the method by which it is introduced into the human body again, it is evident that the actively migrating $F$. loa, that form best known from cases on record, is the semi-adult worm. In some cases this has appeared within about one year after the host has entered infected territory and in other cases as much as five, eleven, or even thirteen years have elapsed since leaving 
such infected regions before the parasite has niade its final appearance in the eye. During this time it has undoubtedly made some growth, and at the end of the wandering stage it tends to settle down in deeper tissue. Here the female probably gives birth to the characteristic muititude of enbryos which in the circulating blood await the chance of being drawn out into a suitable intermediate host, to follow out again the same life cycle. The adult ultimately becomes encysted and calcified by the activity of the tissue of the host, and Brumpt found four out of five adults in this condition in the case he observed.

It will be noted that in reality the discovery of $F . \operatorname{lo} a$ in the eye of a patient in whose blood $F$. diturna is present can not be more than an indication of the relationship of the two; for if the view just advanced is correct the wandering form is not fully mature, and consequently the embryos, if present, must come from $F$. loa of an earlier infection, and not from the form observed at the same time. This would cvidently serve to explain the absence of embryos in those cases, such as Robertson's already noted, where male and female were taken from the eye and yet blood smears from the host showed no microfilariae present. Among natives in a badly infected region successive infections will be the rule, and wandering semi-adult forms will coexist along with parturient females in deeper tissues and embryos in the circulating blood. In hosts infected during a briefer residence in the infected region such conditions would be little likely to obtain, and embryos would be sought successfully in the blood only after the cessation of these migrations, when the worm is said by many to have disappeared from the body.

What time interval is necessary for the attainment of the full grown form is not clear. Certainly migrations continue for many years after infection. In the extreme case noted, a worm was removed from the eye thirteen years after leaving infected territory (case 35 ), and in another, also recorded by Robertson, the parasite is said to have shown itself at irregtilar intervals for fifteen years before final disappearance into deeper tissues. In the case of natives frequent cases of infection in early life 
have been noted; thus the few cases first recorded from the West Indies include two of children, while in Europe that of Lacompte (No. 33) concerns an infant Congo negress. One missionary in Africa notes that the work of the native children in school is interrupted by the periodical visits of the parasite to the eye. This early infection in the case of natives will insure the attainment of maturity by the parasite and the presence of embryos in the blood of the adult negroes even though the development of the parasite proceeds very slowly, while the same slowness in development would render it unlikely that embryos could be obtained from the blood of hosts who had been exposed to infection first in middle life. This would serve to explain the absence of embryos from individtuals as heavily infected as Robertson's patient who, even ten years after the first infection, had no embryos ${ }^{1}$ in her blood (cf. the recent account of this case in Habershon, I904).

Looss (1905:167) has already called attention to certain differences in appearance between the illustrations of $F$. diuma given by different authors. This indicates either a confusion of what are distinct species, as he suggests, or slight differences in structure due to age of the embryos and accompanying growth or ecdysis. The descriptions of these microfilariae are so general as to render a precise comparison difficult. In fact Brumpt originally regarded the embryos which he observed in the circulating blood as a new species which he denominated $F$. Bourgii, but later acknowledged their identity with $F$. diurna. It remains uncertain even yet whether the latter name may not include more than a single species.

\section{TAXONOMY}

All the earlier observers regarded the eye worm as an erratic Guinea worm. In 1805 Guyot recorded the evidence, already quoted in this paper, which led him to the view that it was dis-

1 Ziemann (1905:421) emphasizes the difficulty of determining the fact, and says that to demonstrate the embryos in the blood it is necessary often. to try for several days and nights and to take blood from the region of the swellings. The distribution of the microfilariae in the body is exceedingly irregular. 
tinct from that species. He also noted the name Loa under which the form was known to the natives. Later authorities denominate this a generic term for worm rather than a distinct designation for this form. The citation of the date 1778 is certainly incorrect as his paper was first published in I805; apparently also he does not tise the binomial form Filaria loa at all, so that, if adopted, this name must rest upon some later authority. I do not feel called upon to suggest any change at present.

Despite Guyot's view of its specific distinctiness the parasite. continued to be confused with other forms or to be denied specific rank as late as $185 \mathrm{I}$, the appearance of Diesing's monograph. In $\mathrm{I} 88 \mathrm{I}$, after having had opportunity to examine a specimen sent from Loango, Leuckart passed definitely and favorably upon the question of its distinctness; and in 1886 Blanchard's paper settled finally the rank of the species. The work of many later authors has aided in strengthening the position then assigned to it.

The parasite certainly belongs to the genus Filaria as now generally accepted, and the proposal of Diesing and Cobbold to transfer it from this to the related genus Dracunculus which inclucles the Guinea worm was so evidently an crror that in a later edition Cobbold himself reversed his former action.

The synonymy of the species is confused and depends in part on the positive determination of specimens for which no accurate ciata can ever be given. A partiai list of the names used by various atthors is given here for reference.

Filaria medinensis Gmelin I788, in part.

of Diesing $185 \mathrm{r}$, in part.

Filaria lacrymalis Dubini 1850 , nec Gurlt $\mathrm{I} 83 \mathrm{I}$.

Dujardin $\mathrm{I} 845: 46$.

Filaria oculi humani Dujardin 1845:46.

Filaria oculi Gervais et van Beneden 1859:142; nec von Nordmanni 1832 .

Moquin-Tandon 1859 , in part.

De Bonis 1876:1 29. 
I'ilaria subconjunctivalis Guyon 1864 of Braun 1902.

This term is not used by Guyon himself either in this paper or elsewhere so far as I can ascertain.

Filaria loa Guyot of Leuckart 1876:619.

of Davaine $1877:$ cvii, +839 .

of Cobbold I879:205.

of Blanchard 1886 .

of Stossich I897:2I.

Filaria loa Guyot $\mathbf{I} 778$ of Railliet $\mathbf{1} 893$.

of Braun 1895 .

of Moniez I896.

of Braun 1902.

Dracunculus oculi Diesing $1860: 697$.

loa Cobbold I $864: 388-89$.

\section{GEOGRAPHICAL DISTRIBUTION}

The first six cases of Filaria loa recorded were all from the West Indies and the adjacent coast of South America, while among the first twenty-one cases listed twelve were from that same region and only nine from Africa. In all of the cases from the West Indies and South America the hosts were negroes with the exception of the creole child of case 6 .

As already noted, this case would seem to indicate the existence at that time (approximately r795) in St. Domingo of an endemic center for this parasite. But this is the only evidence that Filaria loa has at any time gained a footing in the lands into which it has been introduced. It is noteworthy that since I845, the date of case $2 \mathrm{I}$ mentioned above, no one has recorded the occurrence of this parasite in the West Indies or in South America. Apparently its occurrence in that region stopped with the cessation of the slave trade, for all of the cases noted were in negroes, and in some cases it stands definitely recorded that they had come from Africa. Thus the worm which Mitchell saw in 1845 (case $2 \mathrm{I}$ ) had apparently been seen eight years before, and the host, a young negress, had come from Africa in I834. The single exception, beyond case 6 already discussed, 
was in case 19 where the worm was removed from the orbit of a negress said to belong to the Mina race of Brazil. It must be noted that at best the determination of the species in these twenty caises is only probable, and confusion with Dracunculus medinensis is not excluded, while possibly rare cases of native American species showing similar habits may also be included. In any event it is important to note the complete disappearance of these cases from the West Indies and South America just about three-quarters of a century after the first one was recorded. Thus far also the negro race might be looked upon as the distinctive host of this parasite, as indeed some authors maintained even much later than this date.

The first recorded specimens which had been taken from Caucasians were described by Morton (1877) and Bachelor (1880), while the next, that sent Lenckart from Loango and described by him in I88I, is also the first one positively identified as a distinct species capable of differentiation from the Guinea worm with which the majority of previous observers had classed this parasite. Following close upon this case numerous others in Caucasians definitely established the fact that the parasite exhibits no racial preference in its hosts.

The first case recorded in Europe was that of the French physician Lota (case 30), who had previously lived in Gaboon and after his return to France found himself infected. In this case the parasite was not removed. In France there have been listed four other later cases (Nos. $5 \mathrm{I}, 52,74$, and 78) in all of which the parasites were removed. All five cases probably originated in the French Congo. A time interval of fifteen years separated the first from the other three.

The French Congo was also the probable source of infection in the single case in which the worm was extracted in Switzerland (No. 3I) and in that from Belgium (No. 33). The first specimens extracted in Germany (No. 42) probably came from western Africa, even though the extensive travels of its host render the exact region of infection impossible to determine; the second (case 8I) from Kamerun. In England six specimens have been removed. In the first five cases the source of the 
infection was Old Calabar, in the last it was the Congo. Australia has had one case (No. 46) in a host who had resided previously on the Gold Coast.

liegarding the presence of Iilaria loa in the western hemisphere Clemow (1903:610) writes that "formerly it was said to have been seen from time to time among negroes in America, but since the slave trade from Africa to the New World has ceased this parasite is no longer found on the other side of the Atlantic." This statement holds good for the West Indies and South America, where, as already noted, no cases have been recorded since 1845 . But as regards the northern hemisphere it is doubly incorrect, both as to former times and as to present records. On the one hand, it is noteworthy that no cases are listed on the North American continent from the days of the slave trade. One can hardly believe that such did not occur, but they seem to have escaped record in the literature so far as I have been able to follow it. On the other hand, there are not wanting recent cases in North America. The first case which actually occurred within the United States (No. 3I)- was reported in i8go. Here the host had sheltered four of these parasites, three of which were removed in this country. There are, to be sure, earlier records of Filaria loa in American literature, for Leidy had examined and reported.briefly in 1877 on a specimen sent Morton from Gaboon by Rev. Dr. Nassau, an American missionary. Also in I880 Dr. Bachelor reported on a specimen he sent from Gaboon, said to be the first perfect specimen of Filaria loa seen in the United States.

The second specimen reported in this country was that of Milroy which I recorded in 1902, and previous to the appearance of the present paper no others were found on record as having been, removed in the United States. In the preceding pagres (p. 3, ff.) I have discussed two specimens of Loveland, one of Friend, and one of Vail, which must be added to the list. Of these six specimens the first was probably acquired in the French Congo and the other five in Kamerun where the hosts had been resident. Two cases (Nos. 68, 69) have been recorded from Canada in 1903 and are fully discussed in the preceding pages. 
It is noteworthy that all of the persons affected were missionaries in those regions, and all but one had suffered from the presence of more than a single specimen of the parasite, which fact points distinctly to its prevalence in the regions in which they had lived. In further support of this view may be cited also their own testimony on this point as already given.

In the foregoing paragraphs have been analyzed all cases of this parasite from other regions than Africa, and it has been shown that they are widely scattered both in time and in space, and also that in all cases there is an apparent connection with a previous residence of the host on the African continent. It is accordingly fit to examine more in detail the evidence concerning the abundance and distribution of $F$. loa in that continent.

All records indicate that the West Coast of Africa is the proper home of the parasite. One case which is reported from Sierra Leone marks its northern limit of extension. And even here the author (Prout, I902) emphasizes the fact that no previous cases had been reported in this region, and that the patient had been living on the Congo, so that the infection probably occurred in the latter place. The specimens of Looss (1904) came from the Gold Coast, but no further information as to their source has been published, nor are other cases from this region on record, although the host in case 46 is believed to have become infected in this territory and said such cases were common in that region.

From this point onward along the coast towards the south every territory has furnished many records of this disease. In Nigeria ten cases are on record in my list, from Old Calabar five cases, from Kamerun eight cases, from French Congo twenty cases, from Angola six cases. Eight cases are not precisely located, but belong to some part of this Western Coast. In addition it has already been noted that the thirty-six cases of this parasite from Australia, Europe, and America owe their infection with great probability to this same region, eight being traced clearly to the Congo, eight to Kamerun, and six to Old Calabar, while in one case the host has visited this entire region at intervals. 
Clemow is in error when he writes (1903:6ro) that it seems to be absent from Kamerun. In a monograph on the Kamerun coast Plehn ( 1898 ) recorded four cases in man and other facts regarding this parasite which demonstrate unmistakably its endemicity in that region. To this evidence one must add that given in the present paper on cases in Americans who were undoubtedly infected in that same state where they resided as missionaries for some time.

These facts indicate that the parasite is distributed over the entire coast from about $5^{\circ}$ north of the equator to at least $10^{\circ}$ - south, and various observers say that in certain regions nearly every inhabitant suffers from it. This is recorded for the Ogowé river by Miss Mary Kingsley, the well-known African traveler ( $1897: 686$ ).

How far it may penetrate into the interior of the continent is as yet unknown. Certain it is, however, that cases occur more than 120 miles from the coast (Yarr, I899), while a recent paper (Brumpt, 1904) records its presence in a post-mortem made in Kassai, approximately 600 miles from the coast on one of the chief tributaries of the Congo. More precise knowledge of the life history, especially of the intermediate host and means of transfer of the species, would enable one to give a better estimate of its range. Apparently the blood-inhabiting embryos which are now regarded as belonging to this species have a much wider distribution than $F$. loa itself.

Thus it is true that Filaria diurna has been recorded as far inland as Uganda, Central Africa, where Cook (IgOr) saw two cases. Onie should bear in mind that our knowledge of the microfilariae is not sufficiently exact to enable the positive assertion that no other form exists in Africa which might be confused with the embryos of Filaria loa. But granting the certainty of the determination, there yet remains reasonable probability that the men in question were infected at a distance from the place in which they were examined. Cook also records in Uganda one case of Dracunculus medinensis, showing the tendency of movements over the great trade routes of the continent to bring together this species and Filaria loa which in general 
have each its own territory and so far as present records show do not occur together in any region.

The occurrence of Filaria loa in negro slaves, in travelers, in government officials, and in missionaries points otit distinctly the certainty with which any kind of intercourse between nations and geographic areas tends to transfer to new races and territories the diseases of the old. Increased means of communication and growing freedom of movement contribute clearly to the spread of maladies and call for better means to check their advance into new regions. It is not to be doubted that some of the persons who brought $F$. loa into the United States now harbor its embryos in the blood. Though we know nothing precise of its life history, the possibility lies close at hand that some blood-sucking insect may furnish these embryos proper conditions for further development and may thus bring about the introduction of a new disease into our territory. Such cases as these of $F$. loa show clearly the gradual spread of disease through national intercourse.

\section{Pathology}

SEAT OF THE PARASITE

In many cases no more definite information is given than that the parasite occurred, in the eye. In the absence of more specific details this may probably be construed to mean crossing the eye- ball beneath the conjunctiva but above the cornea or sclerotic; in numerous cases, indeed, such a location is definitely assigned to the parasite. All in all, this is the most usual position of $F$. loa in the cases thus far on record; however, for reasons to be fiven later it is probably only an accidental occurrence and not the normal seat of the parasite. While most frequently recorded on the surface of the eyeball yet accurate records are not wanting to show that the parasite does occur, if infrequently, within the bulbus oculi. From the anterior chamber $F$. loa was removed in the case of Mercier (No. 4, bui not in No. 5 as Kraemer incorrectly says), also in the case of Bachelor (No. 27), of Lacompte (No. 33), and possibly of Barkan, if this most doubtful account be interpreted as concerning $F$. loa. 
From the lens this species has not been extracted, and those cases in which such a form has been reported from the vitreous humor are most uncertain. They rest in the main upon determination in life by the ophthalmoscope. But this method of procedure has resulted, in some cases at least, in confusion with a persistent hyaloid artery of peculiar form, as in the descriptions of Eversbusch, Fano, Malgat, Quadri, and Schöler, while the oft cited account of Kuhnt concerns a peculiar small nematode, certainly not the species under consideration.

Roth is of the opinion that these parasites leave the eye by way of the nasal duct. More probably this is only apparently true, since, as Dr. Friend suggests (p. 5), the worm nearly always goes out of view by way of the inner canthus.

Outsicle of the eyeball $F$. loa has been reported at least ten times as occurring in the eyelid, both upper and lower lid having been infected. From this position it has been removed six times or more.

$F$. loa has also been reported as wandering back into the orbit, as in cases 14, 19, and 22, and while no one of these cases is beyond doubt as to the species in question or the location of the parasite, there seems to be no question, on the other hand, that the loose connective tissues of this part afford the most ready resting place from which the parasite may make its excursions over the cornea at short intervals, as reported by several observers.

When in other parts of the body than the eye the parasite eludes observation in general, but it is important to note that nevertheless it has been seen and extracted many times in other regions, especially in the subdermal connective tissue. Thus it has been observed to cross the bridge of the nose from eye to eye (case 38 ); it has been excised from below the loose skin of the back (cases $3 \mathrm{I}, 54,88$ ), from the skin above the sternocleido-mastoid muscle (case 94), the sternum (case 69), and the left breast (cases $72,73,94$ ), from the lingual frenum (case 74 ), from the loose skin of the penis (case 59); it has been seen beneath the skin of the fingers, both in himself and in others, by the Rev. Dr. Nassau, a missionary long resident in Gaboon 
and well known as a student of the religious and social customs of the negro races; it has also been extracted from the metacarpo-phalangeal articulation (case. 87). Ziemann (1905) records that the worm is said by his patients to wander about under the scalp, and others maintain its presence in various other parts of the body. According to report of post-mortems the adult form occurs almost anywhere under the skin, but especially in the appendages (cases 78,80 ).

In view of all the evidence the superficial connective tissues must be regarded as the true seat of the adult parasite, and its occurrence in the eye or indeed in other adjacent parts is more or less accidental and occasional.

\section{EFFECT ON THE HOST}

When in the eye $F$. loa is the cause of temporary piercing or lancinating pains as it makes its way through the connective tissue. This pain is also accompanied by the sensation of a foreign body in the eye, and in case it crosses the field of vision there is added an uncertain image of the object. Both the pain and the sensation of the presence of some foreign body cease promptly with the withdrawal of the parasite into deeper tissues, while even repeated visits leave no permanent effect upon the organ other than to produce a very slight elevation of the conjunctiva, as Lota reports from observations on himself which one may consult (p. 49) for further cletails. In fact, the annoyance is so slight and of such brief duration as hardly to call for medical aid at all. Removal from the eye is not difficult when regard is had to the activity of the parasite and its tendency to flee at once when touched by any instrument. Even the natives in Africa practice its extraction with the rudest sort of instruments, in some cases using only a hooked thorn. In the earliest cases observed by European physicians it is recorded that such removal is unaccompanied by any untoward symptoms and is followed by complete recovery in a very brief time. So far as I have found, the same results uniformly follow the removal of the worm, from the anterior chamber as well as from below the conjunctiva. 
In the eyelid the $L o a$ is apt to give rise to a slight tumefaction at least, and this may simulate entirely different conditions. Thus in the case recorded by Dr. Thompstone (No. 36) the parasite lay in the lower lid at the inner canthus close to the lachrymal sac, the swelling in that region giving the appearance of dachryocystitis. When an effort was made to press out the contents of the sac, the worm wriggled away.

$F$. loa may migrate from point to point under the skin without producing any visible effect upon the parts invaded. Thus in different cases it has been watched in its migrations from the eye to the forchead, or over the bridge of the nose to the other eye or under the skin of the back or chest; and in all of these it is not recorded that any modification of the normal appearance of the part followed the movements of the worm. One of the most distinct and trustworthy of these observations is that quoted from Starr in the present paper (p. 6).

\section{CALABAR SWELLINGS}

The first publications I have found on the nature of Calabar swellings (the Kamerungeschwülste of the German authors) are in the book by Plehn ( 1898 ) and a contribution exclusively on this topic by Thompstone (1899), a district medical officer in Old Calabar. To be sure they were recognized as a distinct disease much earlier, and are referred to under this name by Robertson (1895). Since then numerous references have been made to their occurrence, and several observers have discussed at length their character and cause. They are apparently spontaneous and fugitive in character, appearing suddenly and requiring two to three days to disappear. In size half that of a goose egg, they may occur on any portion of the body, though according to most they apparently favor the extremities. They are painless and do not pit under pressure. According to Thompstone they come one at a time and recur at irregular intervals of time. He also states they are somewhat hot both objectively and subjectively, while Joseph (1903) states distinctly that they are accompanied by no temperature. 
Robertson ( 1895 ) was apparently the first to call attention to the fact that his patient, afflicted with $F$. loa, also suffered from Calabar swellings. Later observations on the same patient (Robertson, I897) record an immediate recurrence of the trouble on return to Old Calabar, where itching behind the eyes and swellings on the arms are almost universal among the natives. $\mathrm{He}$ also says that when the parasites are felt moving, headache and nausea as well as puffy swellings of the arms are troublesome, while all parts of the body may.be affected, especially the scalp.

In regard to the cause of these swellings, Manson (1903) sums up the case well when he says, "Their peculiar geographic range, which it would seem includes the Congo basin, the fact that they come and go, the fact that they persist in recurring after the subject has left the endemic districts, render it practically certain that they are of parasitic origin." In the same paper he reports a series of eight cases of the disease among mišsionaries on the Upper Congo, two of which had been under his personal care. He further notes the general association with $F$. loa, and conjectures they may be due to the parturition of this species. Their association with $F$. loa and possible relation to that parasite had already been commented on by Robertson. The absence of $F$. diurna, the conjectured embryonic form of $F$. loa, as shown apparently by his blood tests, may easily be due to failure to make preparations at the proper time or place. Furthermore, the geographic distribution of this malady is much the same as that of $F$. loa, which would further strengthen the view that there exists a causal relation between the two.

More recent publications have brought forward additional proof of this causal relation. Thus Habershon (1904) has presented strong evidence in favor of the view, when he reports that almost every European at Yakusu suffers, and adds details of several cases which were under careful continuous observation and showed the presence also of $F$. loa. In one case the attack commenced with the most intense neuralgic pain, followed by swelling of the part affected, which began a few hours later and was comparable to an attack of acute myositis. Kerr (1904) also adds evidence on the relation between $F$. loa and the Calabar 
swellings in a series of four cases. Apparently Ziemann (1905) has been able to demonstrate the embryos in the swellings, as he explains the difficulties attendant upon the demonstration. $\mathrm{He}$ seems to think, however, that these swellings are due to $F$. perstans, which in his opinion is the embryonic $F$. loa, while $F$. diurna does not differ from $F$. Bancrofti. He is in accord with previous authors in holding that $F$. loa remains mostly hidden in its wanderings, but causes inflammation in the subdermal connective tissue. Wurtz et Clerc (1905) found in their case of infection with $F$. loa that a tumefaction was produced on the right cheek when the parasite was wandering about in the region of the cye. They also added the important observation that a pronounced intense eosinophilia was associated with the presence of $F$. loa in the system. It should be noted that the general symptoms of this case point unmistakably to the presence of a number of parasites and the extreme character of the eosinophilia noted was perhaps due to the multiple infection.

The view that in some way Calabar swellings are related etiologically to the parasitism of $F$. loa rests thus on strong presumptive evidence, and it is timely to consider the theories which have been offered to explain the pathological conditions noted. It is clear, without further discussion, that the mere presence of the parasite as of a foreign body of equal size would not be sufficient to evoke the swellings. It is equally evident that the constant limitation of the worm to the connective tissue, especially in the subdermal region, would throw out of consideration the introdiction even occasionally of foreign matter of any sort and limit the problem clearly to the parasite itself and its own activities and products, working upon the normal tisstes with which it comes in contact.

The earliest suggestion marle was that of Robertson that to the migrations of the Loa are clue these swellings which are associates with its presence. Careful study of the data recorded in connection with the various cases seems to show, however, that mere movement can not be the exciting cause. Note first that the swellings are local and infrequent; now mere migrations, if effective, ought to produce linear tumefactions conforming to 
the path the worn has followed, if not immediately coincident in time with its movements. There is one record of such movement of the swelling, given by Milroy in the present paper ( $p$. 47), but another similar observation has not been noted, and there is much indirect evidence to show that it does not occur ordinarily at least. In fact, these swellings are usually described as oval, circumscribed, and of relatively small size; hence the stimulating factor must be a variable or occasional one. Furthermore, the swellings are single or rare, while it is indisputable that the migrations of the worm are constant and considerable. Its activity and freedom of movement have been commented upon by many observers, and are manifest both in the eye and elsewhere in the body. This striking contrast between the pathological conditions and the parasite supposed on good grounds to produce them can only be explained by the assumption that the exciting factor is an intermittent element in the biology of the parasite, of relatively infrequent occurrence. In further support of the view that the pathological condition is not the result of the mere movements of the parasite may be urged the record of observations concerning its movements under the conjunctiva. The unanimous testimony of observers is that the parasite produces no change whatever in the appearance of the organ, as it moves across the surface of the eyeball, nor is any alteration visible subsequently save an insignificant elevation of the surface. Similarly, it has been seen moving under the skin in other parts of the body without pathological changes resulting. Important additions to the previous records on this point are found in the observations of Friend, Starr, and Loveland included in the preceding pages.

Manson reports the statement of one of his patients that the erythema and swelling are due to mechanical excitation when the region of the parasite is rubbed. Indeed, this lady, long resident in Old Calabar, informed him that if rubbing or scratching is not indulged in when a Loa approaches the surface there will be no swelling. It is difficult to see how the rubbing could produce such definite areas or how the number and frequence of the swellings could be so limited. Furthermore, Milroy records the 
evidence of his patient that such a swelling may be rubbed to remove it, so that the evidence is at least somewhat confused.

It can hardly be that the parasite in its migrations stimulates nerve fibers or endings and thus produces as secondary results the conditions ; for any excitation of sensory elements is inadmissible, as the swellings are distinctly declared by most authors to be painless. Hence Blanchard's suggestion of similarity to the symptoms evoked by Hypoderma lineata, a fly larva that carries out subcutaneots migrations, hardly meets the conditions of the case. Looss (1905) calls attention to a more striking parallel between the Calabar swellings and those seen at times in cases of Sparganum Mansoni, a migrating cestode larva which occurs in the East.

Hardly more acceptable as an explanation of Calabar swellings is the view that the Loa in its movements stimulates unduly reflex or sympathetic fibers. The infrequence of the swellings and their distribution as compared with the nervous elements speak distinctly against the supposed relation.

Convinced of the insufficiency of previous efforts to explain the tumefactions, Manson (1903) advanced the view that they are caused by the discharge of embryos-into the tissues. This discharge of embryos from the parental form is intermittent, and would produce the swellings by acting as a mild irritant and causing a transient edema. In most respects this view meets the conditions thoroughly, and it can hardly be said that definite facts are recorded as yet which it fails to explain. Yet its acceptance involves distinctly the concession that not all cases of infection with $F$. loa are subject to Calabar swellings; for when the host harbors the male parasite alone, or also only immature females, there can be no discharge of embryos into the tissues and consequently no swellings produced. The theory of Manson conforms to the facts in so far that cases of $F$. loa are on record and are also distinctly noted by physicians (Ziemann, 1905) in the infected region in which Calabar swellings do not occur. On the other hand, there are cases in which the swellings are found at such an early period after the coming of the host into infected territory that the Loa could not have 
reached sexual maturity. As already emphasized, all the evidence points to an extremely slow growth of the parasite and to conformable delay in reaching sexual maturity. Unless this evidence has been entirely misconstrued, and a more rapid attainment of sexual maturity is possible under some undetermined circumstances, the view of Manson fails to account completely for the facts in the case. In the case of Milroy the swellings began within two years from the time of entrance into the infected region; furthermore; the parasite extracted three years later was a male, and so far as known only a single parasite has been present in the body of this patient.

In view of these facts I venture to suggest another feature which may not be without its bearing on the production of these swellings. The parasite will, from time to time, discharge from its body waste materials which in their very nature are toxic and hence likely to cause such local changes as the Calabar swellings. The action in this case would be chemical rather than the mechanical irritation from the discharge of embryos. The ultimate decision in this matter must necessarily await the accumulation of further evidence. So far as facts at present on record are concerned none of the causes advanced thus far are sufficient to explain the rarity of the tumefactions in cases of multiple infection by the parasite.

\section{Clinicil Data}

\section{CLINICAL.NOTES ON CASES 53 AND 54 \\ IBY W. F. MILROY, MI.D., OMAIA}

Batanga is a settlement situated in German territory, on the western coast of Africa in about $3^{\circ}$ north latitude. In I $897 \mathrm{Mr}$. $\mathrm{K}$, an American of German parentage, became a resident of this place. About two years later he first observed upon his body a tumefaction which, in that country, is known to foreigners as "the African swelling," and which is by common consent attributed to a parasite. To the natives this parasite is known as the eye worm because of a disposition it exhibits to. frequent the neighborhood of that organ. 
That the swelling is caused by this parasite seems not to be a fact absolutely established. However, upon one occasion within the knowleclge of $\mathrm{Mr}$. K., one of these upon the dorsal surface of a woman's hand, being rubbed with a view to removing it, the parasite was seen to emerge from the tumefaction and make its way across the metacarpo-phalangeal articulation, from which location it was extracted. Upon another occasion the swelling appeared, upon his own person, over the right frontal eminence. Within an hour it had extended downwards across the supraorbital arch, along the right side of the nose, and outward beneath the eye as far as the outer limit of the orbit. During this process, when the swelling reached the side of the nose, the movements of the parasite became visible beneath the skin and upon the surface of the tumefaction, where it was seen to cross below the eye, and the sharp, stinging sensation was apparent to its loost as it made its way downward across his cheek. From these and similar observations there would appear to be little room to question the correctness of the assumption that the occurrence of this swelling is conclusive evidence of the presence of the parasite.

The swelling is from three to five or eight centimeters in diameter and not greatly elevated. The appearance of its cutaneous covering remains normal. A sharp stinging or smarting sensation with more or less itching attracts attention where the swelling is about to appear. The swelling is indurated and is sometimes accompanied by great pain, but in other cases pain is absent. From its first appearance until the part returns to its normal condition a period of two or three days elapses. It occurs upon the head or face, the wrists, hands or fingers, the ankles, feet or toes. It is seldom seen upon other parts of the body. This may be accounted for by the relative deficiency of subcutaneous connective tissue in the parts mentioned. When the joints of the extremities are involved, marked stiffness and pain are felt on motion, and in some instances creaking of the joint so marked as to sometimes be audible at a distance. No distinction of age, sex, or condition exists as to susceptibility to invasion of this parasite. The host is never aware of its presence 
except when it approaches the surface of the body, and no constitutional symptom is recognized as due to its presence. So far as known to $\mathrm{Mr}$. $\mathrm{K}$. no permanent harm has ever resulted from its occupation of the human body.

In February, I902, Mr. K. came to me for the removal of his "eye worm" which had made its appearance beneath the cutaneous surface of the upper lid of his right eye. Its movements were readily visible. A fold of the skin was firmly seized with a forceps so as to include the moving body, an incision was made near the forceps and after a search of fifteen or twenty minutes a portion of the parasite appeared in the wound; this was seized and the animal extracted. Since the first appearance of the parasite in his body in 1899 , it had shown itself at points as remote as the sole of the foot and the face. He sometimes was unaware of its presence for two or three months continuously, but it was usually manifest at much shorter intervals. Previously unsuccessful efforts had been made to remove it from the inner side of his left arm, below the nipple on the left side, and near the lower angle of the left scapula. As a rule, having appeared at an accessible point it was gone before a surgeon could be reached. Mr. K. stated that he had experienced no inconvenience from the presence of his tenant except when it approached the surface of his body where it usually remained but a very short time. On one occasion it gave rise to violent pain as it made its way across the sclerotica below the iris of the right eye.

Since the extraction of this specimen four months have elapsed with no recurrence of the symptoms. Whether more than a single specimen has ever existed in the body of this gentlemen he does not know, but during the period of about three years, from the first sign of its presence until the extraction of the parasite in February last, the characteristic manifestations have never appeared simultancously at more than one point.

OBSERVATIONS OF LOTA

To these notes of the case of Milroy it is valuable to append another little-known record quoted by Terrin. It is an interesting account which gives the following clinical picture of $F$. loa 
and comes from the observation of a French physician, Lota, who had opportunity to study the action of the worm in his own eye.

After his stay in Gaboon and return to France, Lota suffered oft-rccurring conjunctivitis with which he was not previously afflicted. Suddenly he felt in the right eye a sting without outward cause, and a feeling of heaviness which was unpleasant, while at the same time there arose an active injection of the conjunctiva bulbi. These symptoms disappeared on application of cold lotions to the eye, but recurred in a few days. Lota attached no importance to the matter. Five months after his return he was awakened from sleep one morning by a sharp pain in the right eye. He had the sensation of a foreign body under the upper lid, accompanied by frequent winking. As he drew up the upper lid before a mirror, he noticed the conjunctiva was reddened, swollen, and slightly elevated. He recognized under it a yellow irregular mass without being able to determine its nature. The sensation of a foreign body lasted about two hours and then ceased suddenly. Lota investigated the eye again and could determine only a slight conjunctivitis; the yellow body was gone!

That evening the same symptoms came on again. Lota noted on the sclera a yellow, round body of the caliber of a knitting needle, about 2 to $3 \mathrm{~cm}$. long, which moved itself from the external angle of the eye towards the caruncle, at times straight, again bending itself into $U$ and $S$ shapes; it crept along under the corium above the sclera only to disappear at the inner angle of the eye. Next evening the worm showed itself under similar circumstances below the conjunctiva above the cornea; here it remained a long time so that several colleagues of Lota could observe its presence and movements. It then disappeared again into the depth of the eye and never appeared thereafter. Its presence had induced no further change on the bulb than an insignificant elevation of the connective tissue: The visual power was never disturbed.

\section{Critical Bibliography of Filaria loa}

The accompanying bibliography includes all references to Filaria loa and also all which at any time, so far as I have been 
able to ascertain, have been construed as such, together with the publications which have contributed to the explanation of any doubtful cases. No attempt has been made to include all references to human eye worms other than $F$. loa, although the involved condition of this subject has resulted in bringing together here the majority of these also. The list includes only the more prominent text-books, or such as contain extended discussions or original contributions to a knowledge of this species. For valuable assistance and criticism in the preparation of this bibliography I am indebted to Professor J. I. Wyer, librarian of the University of Nebraska.

In printing these references the two numbers separated by a colon denote volume and page, i. e. 28:5 Io means volume 28, page 5Io. An additional number in parentheses before the two just explained denotes the series and is used only when the volumes of each series are numbered separately from those of preceding series.

\section{Billiography}

Addario, C.

I885. Su di un nematode dell'occhio umano. Ann. d. ottalm., I $4: 135-48$, I pl.

This much-cited paper deals with another spècies, $F$. conjunctivae, identical with the form described later by Grassi as $F$. inermis, a normal parasite of horse and ass, and an occasional one in man. It is entirely distinct from $F$. loa.

Annetr, H. E., Dutton, J. E., Anp Elliots, J. H.

I90I. Report of the Liverpool Expedition to Nigeria, Part II. Filariasis. Thompson Yates Laboratory Reports, $4: 1-93$, I4 pl.

Found $F$. diurna, in a boy of lower Nigeria who was also infected with $F$. loa. Second case of $F$. loa without embryos in blood. Relation of $F$. diurna and $F$. Bancrofti discussed at length; weight of evidence favors identity.

Arrachart, J. N.

1805. Mémoires, dissertations et observations de chirurgie. Paris, $8^{\circ}, 3^{\circ} 2$ pp. 
Mèmoire sur les vers des yeux. Lu à l'Academie de chirurgie en 1778 ; (p. 217) records the cases in St. Domingo known to him and asserts that the Loa is a valid species distinct from the Guinea worm. Reproduces Bajon, 1777, and Guyot, 1805.

Assenava, Saba.

I899. Étude sur la provenance des entozoaires superficiels. Thèse. Fac, med, univ. Nancy, No. 6.

Cites verbatim the case of Lota as Obs. XXII, briefly that of Robertson as Obs. XXIII, and notes in text few other cases without details.

BACHELOR, H. M.

I88o. The Eye Parasite, Dracunculus loa. (Letter to the editor from Gaboon, W. Coast of Africa. Dec. I5, 1879.) Med. Record, N. Y., I7 :244.

Specimen extracted from native young man. The first perfect specimen sent to U. S. A.

1881. Filaria loa and Pulex penetrans. Med. Record, N. Y., 19:470-7r.

Case in white woman, missionary; three worms removed. Dr. Nassat (cf. Morton, 1877) "had one in the areolar tissue between the thumb and index finger."

I881a. Filaria loa and Pulex penetrans. (Trans. IV.=) Bull. N. Y. Path. Socy., (2) I :IO8-I I.

Identical reprint of Bachelor, H. M., 1881.

BAJON, M.

1777. Mémoire pour servir à 1'histoire de Cayenne et de la Guyane françoise. Paris, 2 vols., $8^{\circ}$. Abstr. in Jour. de méd., ( 1778 ) 49:386-408, 48I-97.

Two cases $(1: 325)$ in negroes at Cayenne, in 1768 and 1771. Quoted verbatim by Blanchard (1899) under date of 1778 . Also in Arrachart, $1805: 217$.

I781. Abhandlungen von den Krankheiten auf der Insel Cayenne und der französischen Guyana. Erfurt. Bd. I, II.

Not found. Cited after Kraemer (1899). Probably translation of Bajon, 1777. 
BARKan, A:

1876. A case of Filaria medinensis in tha Anterior Chamber. Arch. Ophth. and Otol., N. Y., $5: 15 \mathrm{I}-52$.

Filamentous object adherent to iris was removed from native Australian and found on microscopic examination to be " $F$. medinensis." Can hardly be $F$. loa, but the absence of data leaves it permanently uncertain. Perhaps an Australian filaria.

1876a. Ein Fall von Filaria in der vorderen Augenkammer. Archiv. f. Augenheilk., $2: 38 \mathrm{r}-82$.

Literal translation of Barkan, 1876.

BARIRETT, J. W.

I896. A case of Filaria oculi humani. Archives of Ophthalm., N. Y., $25: 291-92$.

Worm removed in 1893 from eye of white male who had lived on Gold Coast and had come to Melbourne four years before. Identification probable. First case in Australia.

1897. Ein Fall von Filaria im menschlichen Auge. Arch. Augenheilk., 34:255. Cf. CB. Bakt. u. Par., 22:4r9.

Literal translation of Barrett, 1896.

Bernard, $P$.

I898. Un cas de Filaria loa mâle. Archives d'ophtalmologie, Paris, I8:604-6. Abst. in Jour. Trop. Med., I :I IO-I I.

Removed from white male who had lived in Congo (1894-96). First seen about three years before removal. Identified by Blanchard; second case, first male, of $F$. loa seen in France.

BLANCHARD, R.

I885-88. Traité de zoologie médicale. Paris, 2 vols. $8^{\circ}$.

Exact account with full references to cases of $F$. loa (2:10-12).

1886. La Filaire sous-conjonctivale (Filaria loa Guyot). Le Progrès médical, Paris, (2) 4:591-93, 61 I-12. Also in Rev. clin. d'oculist., No. VII, P. I59 (after Kraemer, I $899: 85$ ).

Fine record of earlier cases with discussion of structure, life history, and relation to eye worms of other animals. Presence in American hemisphere attributed to slave trade. 
1899. Nouveau cas de Filaria loa. Arch. Parasitol., Paris, 2:504-34, I2 figs., Rev. in CB. Bakt. u. Par., 28:457; Zool. Centr., $7: 243-44$.

Complete discussion of twenty-five old and one new case with full. illustrations of structure and data on life history and distribution. Good bibliography.

Braun, $M$.

1902. Die tierischen Parasiten des Menschen. Dritte Aufl. Würzburg, $8^{\circ}, 360$ pp., 272 figs. [Title page date 1903; received here in Dec., 1902.]

F. loa (p. 271); brief, accurate.

BRCMPT, E.

1904. La Filaria loa, Guyot, est la forme adulte de la Microfilaire désignée sous le nom de Filaria diuma Manson. CR. Soc. Biol., Paris, 56:630-32.

In an autopsy on the Congo, $F$. diurna was found in the blood, also a fragment of an adult female filaria in the heart; the latter agreed in all details with $F$. loa, but the absence of head and tail made a final determination impossible. The author regards $F$. loa as an accidental parasite of the eye.

Chiralt, V.

I880. Sobre un caso di filaria oculi. Att. session congress reg. cien. med. I879, Cadiz. Cron. oftal., Cadiz, ( I880-8I) I0:473-80.

Not seen; cited by Kraemer, 1899:85. Probably identical with following reference.

I882. Sobra un caso filaria oculi. Cadiz, Att. session congress reg. cien. med. [of 1879 ], pp. 2-9, I fig.

Not seen; cited by Coppez, 1894:567, as Filaria in vitreous body, p. 473.

Clemow, F. G.

I903. The Geography of Disease. Camb. Geog. Series; 624 pp., maps.

F. loa (p. 609) only on W. Coast Africa, endemic from a few degrees N. L. to about $10^{\circ} \mathrm{S}$. L. Not in America since cessation of slave trade. 
Clot-Bey.

1832. Dragonneau. Revue générale Académie royale des sciences. Séánce $d u$ Io décembre. Archives générales de médecine, Paris, Io ${ }^{\text {me }}$ année, $30: 573$.

Gervais et van Beneden (1859), Davaine (1877), and Rayer (1843) cite the reference as given. I have compared the original and the citation is absolutely correct; there is no hint in the abstract of any other author. The brief description records an observation by the author of a worm in the orbit and crossing the cornea of a slave girl in Monpox, brought from Africa some years before. Yet according to Guyon (1838) Clot-Bey says he has never been in America, and Leuckart (1881), together with later authors, declares the citation incorrect, and all attribute the case to Roulin, by what authority I have been unable to ascertain. 'It does not help the case to read in Guyot (1838) "Als ich mich im Jahr 1828 zu Monpox am Magdalenenflusse in Neugranada befand, führte mich ein dort ansässiger französischer Apotheker zu einer 25 bis 30 Jahr alten Negerin der schon erwachsen aus Afrika herüber transportirt worden war," etc.

Coвbold, T. S.

I864. Entozoa. An Introduction to the Study of Helminthology. London, $8^{\circ}, 480$ pp., 2 I pl., and 82 text figs.

Brief account under Dracunculus loa (p. 388). Defends its specific distinctness. Cites Davaine (1877) for further details.

I879. Parasites. London, $8^{\circ}, 508$ pp., 85 text figs.

Transfers species back to genus Filaria (p. 205). Otherwise as before. Short bibliography.

Cook, A. R.

I90I. Notes on the Diseases met. with in Uganda, Central Africa. Jour. Trop. Med., 4:175-78.

Records (p. 178) the occurrence of two cases of Filaria diurno in this region.

Coppez, $\mathrm{H}$.

r894. Un cas de Filaire dans la chambre antérieure d'un oeil humain. Archives d'ophtalm., 14:557-62. Also in Clinique, Bruxelles, I894, 8:48I-84.

An infant negress from the Congo, worm in anterior chamber; imnature. 
1895. Progress of Ophthalmology. Arch. of Ophthal., N. Y., $24: 284$.

Review of Coppez, 1894.

Cunier, Fl.

I843. As editor reprinted Nordmann, 1843, and Rayer, I843, with comments, etc. Ann. d'oculist., Bruxelles, $9: 136-77$.

Davaine, C.

1860. Traité des Entozoaires et des maladies vermineuses de

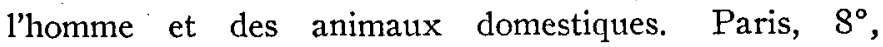
$\mathrm{xix}+\mathrm{xcii}+838$ pp., $37+3 \mathrm{I}$ figs.

Full data on earlier cases.

1877. Idem, Paris, II. ed., cxxxii+1003 pp., $72+38$ text figs. Apparently identical reprint (pp. cvii +839 ) of earlier edition as regards this species.

De Mets, -

I896. Une observation de filaire de la retine. Belgique Méd., Gand-Haarlem, I :737-42. Abst. in Ann. Ophth. \& Otol., N. Y., 5:1097.

Nematodes in urine; not precisely described or identified. Not $F$. loa. Presence in retina inferred.

Diesing, C. M.

I851. Systema Helminthum. Bd. II. Vindobonae.

Under F. medinensis (p. 270): "Habitaculum, homo. . . . rarissime sub conjunctiva oculi (Bajon, Mongin, et Blott)."

I86I. Revision der Nematoden. S. B. math-natw. K1., Akad. Wiss., Wien, 42, Nr. 28.

Lists $F$. loa as Dracunculus oculi (p. 697).

Drake, Brockman.

1894. [Notes.] Ophth. Rev. (London), r3:33r. Also in Ophth. Socy.-Brit. Med. Journ., I894, 2 :92I.

In eye of young woman in Madras, India; worm escaped from puncture and not studied. Blanchard (1899) thinks this is more probably $F$. equina, common in India.

I894a. Cas de Filaria loa sous-conjonctivale. Annales d'oculist., $112: 336$.

Translation of Drake, 1894. 
Dujardin, F.

I845. Histoire naturelle des helminthes ou vers intestinaux. Paris, $8^{\circ}$, avec un atlas de $12 \mathrm{pl}$.

Notes (p. 46) the occurrence in the human eye of a Filaria not yet described, which is certainly different from F. medinensis.

DUYse, -, vON.

I895. Un cas de Filaire dans la chambre antérieure d'un oeil humain. Archives d'ophtalm., Paris, I 5 :701-6.

Same case as Coppez (1894), Gauthier (1895), and Làcompte (1894); worm extracted by latter. Discussion of species and records.

EVERSBUSCH, [O.]

I891. Entozoen im Glaskörper (Mittelfränkischer Aerztetag in Fürth). Münchener med. Wochenschr., 38:532. Also in Jahresb. d. Leist. u. Fortschr. d. Ophth., $22: 305$.

I892. Glaskörperentozoen. Ber. über d. xxi. Versammlung d. Ophth. Ges. Heidelberg, I891 :249. Ausserordentliches Beilageheft zu Klin. Monatsblätter f. Augenheilkunde, 29.

Preliminary report on supposed living worm observed by eye mirror. Extended description not published as promised. Certainly not $F$. loa. Probably persistent hyaloid artery.

Fano, [S.].

I868. Observation de filaire vivante du corps vitré. Union méd., Paris, (3) 5:389-9r.

Observed by eye mirror in child of twelve years; not removed. I868a. Filaire vivante dans le corps vitré. Annales d'oculist., $59: 207-8$.

Literal reprint of Fano, 1868.

1876. Filaire vivante du corps vitré. Modifications survenues dans l'oeil malade huit ans apres le premier examen. Jour. d'oculist., Paris, $42: 17^{2}-74$.

Examination of case of 1868 after eight years. Original text reproduced. Further observations unimportant. Not F. loa. 
GaUthier, C.

1905. Microfilaires du sang coincidant avec the filaire de l'oeil. CR. Soc. Biol., Paris, 58:632-34.

In a patient who had had a filaria in the eyelid were found later embryos like Manson's $F$. diturna but smaller than Brumpt's measurements of the embryos of F. loa.

Gauthier, G.

I895. Filaria oculi humani. Annal. de l'Inst. chir. Bruxelles. Chap. Ophtalm., p. I5.

Not found; probably the same as the following entry.

I895a. Filaire de l'oeil humain. (Annal. de l'institut chir. de Bruxelles, I895.) Ann. d'oculist., I I4:I52-53.

Only a short review by Dastot. Young Congo girl; worm moved rapidly through anterior chamber; not extracted; probably $F$. loa. According to Blanchard (1899) same case as Coppez (1894).

Gervais, P., et van Beneden, P. J.'

I859. Zoologie médicale. Paris. J. B. Baillière et Fils. $8^{\circ}$, 2 vols., I98 text figs.

Case communicated by French marine surgeon, Lestrille, from Gaboon, 1854, given in full (p. 143). Older cases quoted.

Geschiedt, A.

1833. Die Entozoen des Auges, eine naturhistorische, ophthalmologische Skizze. Zeit. f. Ophthal., Dresden, 3:405-62.

An oft cited reference which concerns a small nematode otherwise unknown (cf. Nordmann, 1832), and certainly not $F$. loa. Discussion of eye parasites in other animals.

Grassi, B.

1887. Filaria inermis (mihi) ein Parasit des Menschen, des Pferdes, und des Esels. CB. Bakt. u. Par., I :6r7-73.

Extended description of $F$. conjunctivae, Addario, 1885, (q.v.) and of the cases of this species sometimes confused with F. loa.

GuYon, [J. L. G.].

1838. Note sur des vers observés entre la sclérotique et la conjonctive, chez une négresse de Gùinie, habitant la Martinique. CR. Acad. Sci., Paris, 7:755-56. (Cf. Guyot, I838.) 
Case of Blot who extracted two $F$. loa from a young negress of Martinique that had come from the African Coast. The worms were sent Guyon.

I84I. Note sur un ver trouvé dans le tissu cellulaire sousconjonctival. Gaz. méd. de Paris, 9:106.

Corrects an erroneous reference to the preceding case a's due to cysticerci, and quotes $B$ lot as reporting the patient perfectly well to date.

I864. Sur un nouveau cas de filaire sous-conjonctival, ou Filaria oculi des auteurs observé au Gabon (côte occidental d'Afrique). CR. Acad. Sci., Paris, $59: 743-48$.

One specimen taken from a negro of Gaboon, Africa, and exlended reference to six previous cases, all from America. Gives as the first evidence of the occurrence of $F$. loa a plate printed in Frankfort (Germany) in 1598. This much-cited illustration is shown by Ward (1905) to be fanciful.

I864a. Sur un nouveau cas de filaire sous-conjonctival ou Filaria oculi des auteurs, observé au Gabon (côte occidental d'Afrique). Annales d'oculist., 52:24I-45.

Reprint of Guyon, 1864.

Gurot, - -

r805. In Arrachart, I805. Copied by Rayer ( 1843 ) as Obs. IX.

French naval surgeon records six cases in 1777 from African Coast. Extraction attempted and failed.

Guyor, - -

I838. Ueber Würmer welche sich unter der, den vorderen Theil des menschlichen Auges bedeckenden, Schleimhaut aufhalten. Froriep's Neue Notizen, 8:230-3I.

Cites earlier cases, notes as new that of Blot who sent one specimen to Blainville. This paper is that referred to under Clot-Bey, 1832. This apparently should be Guyon, 1838, with which it agrees, though the German translator has printed consistently Guyot. This same error has been made more recently by Scheube, 1900 .

Habershon, S. H.

1904. Calabar Swellings on the Upper Congo. [Includes letter from D. Argyll Robertson.] Jour. Trop. Med., $7: 3-4$. 
Almost every European at Yakusu suffered. Clinical data. Several cases of Loa briefly noted. Letter gives further history of Robertson's patient, including extraction of parasites not in eye.

Harrison, J. H. H.

1904. Filaria loa (?). Selected Colon. M. Repts., I90I-2, London, p. 46.

Not seen. Cited from Index Medicus.

Henry, F. P.

I896. Remarks on Filaria. Proc. Acad. Nat. Sci., Phila., I896: 27 I-75. 'Rev. in Zool. Jahresb., I896, Vermes, p. 44.

Cites cases and data from Manson and Robertson; rejects Manson's view that $F$. loa is adult of the embryonic blood worm known as $F$. diurna.

HirschiberG, J.

1895. Ueber einen aus dem menschlichen Augapfel entfernten Fadenwurm. Berliner klin. Wochenschr., 32 :956-58, 97 I. Rev. in Zool. Centr., 3 :233; CB. Bakt. u. Par., I8:755. Also I896, Verl. Berlin. med. Ges., 26, pt. 2 :287-94; Centralb. prakt. Augenheilk., 20:27-32, 4 figs.

Female $F$, loa taken from eye of negro in Cayo, French Congo. Review of earlier cases.

Huber, J. CH.

1898. Bibliographie der klinischen Helminthologie. Supplementheft. Inhalt: Filaria (excl. F. sanguinis hominis), Strongylus, Gnathostoma, Strongyloides, Rhabditis, Pentastomum. Jena, $22 \mathrm{pp}$.

F. loa (pp. 3-5); doubtful cases (p. 6). References arranged by countries, brief annotations.

Joseph, E.

I903. Medizinische Mittheilungen aus unseren westafrikanischen Kolonieen. Dtsch. med. Woch., 29:I45.

Describes Kamerun swellings as occurring anywhere, but especially on extremities. Not painful, no temperature, cure spontaneous in few days.

KERR, T. S.

1904. Calabar Swelling and its Relationship to Filaria loa and diurna. Jour. Trop. Med., 7:195-96. 
Cites theories of Manson and Robertson regarding Calabar swellings. Records cases of Habershon, Wurtz, and Hanley. Thinks this evidence demonstrates relation of $F$. loa and its embryonic form $F$. diurna to the trouble.

1905. [Abstract.] Arch. f. Schiffs u. Tropen-Hyg., 9:18I.

1905a. Kalabarbeulen und ihre Beziehungen zu Filaria loa und diurna. Münch. med. Wochenschr., 52:474.

Review of Kerr, T. S., 1904.

Kingsley, Mary H.

1897. Travels in West Africa, Congo Français, Corisco, and Cameroons. Macmillan \& Co., London, $8^{\circ}$.

Under diseases the author notes "lastly, a peculiar abomination, a filaria. . . . I have seen the eyes of natives simply swarming with these filariae. . . A similar but not identical worm is fairly common on the Ogowe and is liable to. get under the epidermis of any part of the body:"

Kraemer, A.

1899. Die tierischen Schmarotzer des Auges. IV. Die Fadenwürmer (Filariae) des Auges. Gräfe-Samisch Handbuch, II Theil, $\mathrm{X}$ Band, Io und I I Lief., xviii Kapitel: 64-87, figs. 7-9, I82 pp., I7 figs. Rev. CB. Bakt. 1. Par., $28: 517-18$.

Full record of earlier cases with unfortunate misprints in names and dates; includes under $F$. loa doubtful cases and also Addario, determined by Grassi as $F$. inermis. Says $F$. loa occurs in eyelids and fingers, though Morton, the authority cited, only gives this as the opinion of Nassau; believes $F$. loa and also the Guinea worm may wander back into tissue of orbit.

Kunnt, $H$.

I888. Extraction eines Fadenwurms (Filaria) aus der Regio. macularis des menschlichen Glaskörpers. Corr. B1. allg. ärztl. Ver. Thüringen, 17:54I-55.

Original not seen. Cited thus by Kraemer, 1899.

1892. Extraction eines neuen Entozoon aus dem Glaskörper des. Menschen. Archiv. f. Augenheilk., 24:205-29. 2 figs.

Peculiar small nematode, not identified by Leuckart, not $F$. loa. Removed by operation from the vitreous body. 
LACOMPte, C.

1894. Observation d'une Filaria oculi dans la chambre antérieure de l'oeil d'une Congolaise ; extraction de l'entozoaire. Annales soc. méd. de Gand, 73:375-86.

Observation brief (pp. 375-77); report on same (pp. 378-86) identical with Van Duyse (1895) who is also named here as on the commission.

LALLEMANT, [L.].

1844. Filaria im Auge eines Negers. Casper's Wochenschr. f. d. ges. Heilkunde, $1844: 842$.

From negro in Rio Janeiro, broke in removal, case regarded as unique, but assigned to Guinea worm.

-LARREY, D. J.

I8r2. Mémoires de chirurgie militaire et campagnes. Paris, 4 vols. (I8I2, I8I2, I8I2, I8I7).

Cites de Lassus $(1: 223)$ on Filaria loa. Copied verbatim by Blanchard, 1899.

LASSUS, -, DE.

Reported by Larrey (1812:223, q.v.).

LEIDY, JOS.

I877. See Morton, T. G:, I877.

LESTRIILLE, - -

Reported by Gervais et van Beneden ( $1859:$ I43, q.v.).

LEUCKART, R.

I863-76. Die menschlichen Parasiten, etc. 2 v. $8^{\circ}$. Leipzig.

F. loa (2:619-22). Full analysis of 'older cases.

I881. Bericht über die wissenschaftlichen Leistungen in der Naturgeschichte der niederen Thiere während der Jahre I876-79. Arch. f. Naturges., I877, $2: 397$.

Cites Morton (1877), adds case from European on Loango Coast, examined worm and pronounced $F$. loa a good species. Though bearing the date of 1877 and ustrally quoted as such, this article includes data up to 1879 . It was received by the Harvard Library in Dec., 1881. I adopt this year as the date of the paper. 
Linschoten, Jan Huyghen van.

I596. Itinerario. Voyage ofte Schipvaert von Jan Huygen van Linschoten naer Oost ofte. Portugaels Indien, etc. t'Amstelredam. Cornelis Claesz, $4^{\circ}$.

This work, of which only three editions' are noted here, is often incorrectly cited as giving evidence of the occurrence of F. loa in Africa in 1598. (Cf. Ward, 1905.) This, the original edition, has not the plate supposed to illustrate the extraction of $F$. loa.

I6Io. Histoire de la Navigation de Iean-Hugues de Linscot Hollandois et de son Voyage es Indes Orientales, etc. Amstelredam, Theodore Pierre, $4^{\circ}$.

This later reprint possesses the plate in question.

1885. The voyage of ... to the East Indies. From the Old English translation of 1598 . The First Book. Edited. In 2 vols. Hakluyt Society, London. (Reprint of edition of $I_{598}$.)

The footnotes of this reprint (pp. 46, 52) disclose clearly the . fictitious character of the plate in question.

Linstow, $O$. von.

1900. Ueber die Arten der Blutfilarien des Menschen. Zool. Anz., $23: 76-84$.

Discusses briefly the form Filaria diurna Manson and the view that this is the larva of $F$. loa.

LONEY, W.

1844. Extirpation of Dracunculi from the eye. Lancet, London, $I$ :309.

English marine surgeon removed $F$. loa from two natives of West Coast of Africa. Description scanty.

Looss, A.

1904. Zur Kenntniss des Baues der Filaria loa Guyot. Zool. Jahrb., Abt. Syst., 20:549-74. I pl.

Extended and admirable account of the anatomy with careful references to earlier work on this phase.

1905. Von Würmern and Arthropoden hervorgerufene Erkrankungen. Handbuch der Tropenkrankheiten, herausgegeben von Dr. C. Mense. I :77-209, 54 text figs, pls. 8,9 . 
F. diurna, p. $167 ; F$. loa, pp. 177-79. Brief but very complete and correct review of anatomy, life history, and pathology so far as known, including account of Calabar swellings LoPEz, E. which are likened to those produced by Sparganum Mansoni.

I89I. Filaria en la camaria anterior. Rev. de cien. méd. Habana, 6:269.

Not found; cited after Kraemer, 1899.

LotA, [F. L.]

I884. [Filaire sous-conjonctivale.] In Terrin, L., I884.

Cited in full in the present paper (p. 49).

Lupwig, $\mathrm{H}$.

I896. Filaria loa. Sitz.-ber. niederrhein. Ges. f. Nat. u. Heilk., Bonn, I896, nat-w. Sect., pp. 50-2. (Sitzung 3 Feb., r896.)

Report of previous papers, including Ludwig \& Saemisch (1895). Added data from Manson's and Robertson's cases.

Ludwig, H., und Saemisch, TH.

1895. Ueber Filaria loa Guyot im Auge des Menschen. Zeit. f. wiss. Zool., 60:726-40, I pl. Rev. in "CB. Bakt. u. Par., I Abt., I9:424-25; Lubarsch-Ost., $3: 6$ I 8 ; Zool. Cent., 3 :209-Io. Schmidt's Jahrb., Bd. 25I ; Ann. Ophth. and Otol., N. Y., 5:1097-98.

Female specimen extracted from beneath conjunctiva of Russian marine officer whose last trip to West Coast of Africa was in 1891. Careful description of anatomy of worm.

\section{MACNAMARA, - -}

I863. Filaria papillosa in the Eye of Man and the Horse.

Indian Ann. Med. Sci., Calcutta.

Not seen, noted by Robertson (1894) and others. Cited after Huber (1898). The date is given 1864 by some authors.

Malgat, [J.].

I893. Filaire ou dragonneau du corps vitré. Rec. d'ophtal., Paris, (3) 15 :280-83.

Case of man in French Alps; description uncertain, probably filament or artery, certainly not $F$. loa. 


\section{Manson, Sir Patrick.}

I891. The Filaria sanguinis hominis major and minor, two new species of Haematozoa. Lancet, London, I891, I :4-8, I5 tigs.

Suggests that $F$ : loa when in the eye has "lost its way" and its proper habitat is some part more favorable for release of the embryos into the general circulation. Queries whether the smaller form, later called $F$. perstans, might not be the larva of $F$. loa. Subsequently he assigned this role to the larger species, now called $F$. diurna.

I893. The Filariae sanguinis hominis and Filaria Disease. Chap. 2I in Hygiene and Diseases of Warm Climates by Andrew Davidson. Edinburg and London, pp. 73885 r, figs. 5 I -78 .

Not on $F$. loa.

1893a. Diseases of the Skin in Tropical Climates. Chap. 24 in Hygiene and Diseases of Warm Climates, by Andrew Davidson. Edinburg and London, pp. 928-95, figs. $80-97$.

Record of F. loa (p. 961) quoted from Morton, 1877. Also case of negro with $F$. loa and later $F$. dituria in blood. Suggests relation.

I895. See Robertson, D. A. I895b.

1898. Tropical Diseases. London, $8^{\circ}$.-

Two new cases noted briefly; relation of $F . l o a$ and $F$. diurna discussed.

I900. Tropical Diseases. London. Revised edition, $8^{\circ}, 704$ pp., II 4 illus., 2 col. pl.

Identical in the main with earlier edition, but adds discussion on Calabar swellings.

1903. Calabar Swellings on the Upper Congo. Jour. Trop. Med., 6:347-48.

Records eight cases among missionaries, two coming under his own observation. The peculiar geographic range, transient character, irregular recurrence of these swellings, and association with $F$. loa, all point to a causal relation. Conjectures the cause as the parturition of $F$. loa; failure to find embryos due to time or incompleteness of observation. 
1904. A Note on Dr. Primrose's Paper on Filariasis. Brit. Med. Jour., I904, 2 :72-73.

Upholds specific distinctness of $F$. diurna from $F$. Bancrofti as against Annett, Dutton, and Elliott. Reports occurrence of $F$. diurna in case of sleeping sickness in Paris at this time.

Maurel, - -

I868. Recorded as Obs. III by Trucy, I873 (q.v.).

Mitchell, $\mathrm{H}$.

I859. Report of a Case of a Guinea Worm in the Eye. Lancet, London, $2: 533-34$.

Young negress taken from West Coast of Africa to Trinidad in 1834; worm first seen in 1837 , again in 1841, 1845; hence at least eleven years in body; had grown from $0.5 \mathrm{in}$. to $2 \mathrm{in}$. Felt in body later, but not seen [?same worm?].

Mongin, - -

I770. Observation sur un Ver trouvé sous la conjonctive, à Maribarou, isle Saint Domingue. Jour. de méd., Paris, $32: 33^{8}-39$.

Earliest known case, negress of St. Domingo; worm extracted.

Moniez, R.

I896. Traite de Parasitologie. Paris, $8^{\circ}, 680 \mathrm{pp}$.

Short description (p. 351), annotated list sixteen cases. Refers in footnote to Guyon's discovery of plate of 1598 showing operation for removal of eye worm. (Cf. Ward, 1905.)

Moguin-Tandon, A.

I859. Éléments de zoologie médicale. Paris, J. B. Baillière et Fils, $12^{\circ}, 428$ pp., 122 figs. [Title page date 1860 . British Museum stamp date 24 De. 59. Also in printed catalogue.]

Brief account, unchanged in later editions and translations.

Morton, T. G.

1877. Account of a worm (Dracunculus or Filaria loa) removed by a native woman from beneath the conjunctiva of the eyeball of a negress at Gaboon, West Africa, with a brief history of the parasite and Professor Leidy's description of the specimen. Amer. Jour. Med. Sci., (z) $74: \operatorname{Ir3-16.~}$ 
Specimen sent by Rev. Dr. Nassau, first brought to U. S. A., dried in transit, description scanty, clinical notes by $\mathrm{Dr}$, Nassau valuable, as he had been infected personally. This and the case of an English trader also mentioned are the first records of infections among Caucasians.

Nakaizumi, Y.

I903. Ueber eine Filaria im Glaskörper des Menschen. Ophth. Klin., Stuttgart, $7: 116-22$.

Brief record of foreign body in vitreous humor which, on account of continued movement, the author regarded as a filaria. The suggestion that it was an immature $F$. loa is inadmissible; if any species, it is more probably $F$. papillosa, or F. equina.

Neve, Arthur.

I895. Filaria loa. [Letter from mission hospital, Kashmir, Jan. 7, I895.] Lancet, London, I895, I :446.

Reports horse with " $F$. loa" in anterior chamber of eye. Specimen lost. More probably $F$. equina common in India.

Nordmann, Alex. von.

1832. Mikrographische Beiträge zur Naturgeschichte der wirbellosen Thiere. Berlin, $4^{\circ}$, Heft. I, Erste Abhandl., pp., I-54.

Gives (p. 7 ) the history of Filaria oculi humani. Small nematode in lens; not F. loa.

I843. Sur les helminthes dans l'oeil des animaux superieurs.

(Extrait du Nordmann, I832.) Arch. méd. comp., I :67I $3, \mathrm{pl}$.

Literal translation of Nordmann, 1832.

1843a. Ueber die Parasiten im Auge der höheren Tiere. Archiv der vergleichenden Medizin, I :67.

Cited by Kraemer 1899. Not found; apparently an unwarranted translation of the periodical name as well as the title of Nordmann, 1843.

NORDMANN ET RAYER.

1843. Helminthes dans l'oeil de l'homme. Annales d'oculist., $9: 13^{6}-77$.

Reprint of so much of Nordmann (1843) and Rayer (1843) as concerns the human eye, with introduction, footnotes, and summary by the editor, Cunier. 
Ozzard, A. T.

1903. Filaria loa. Jour. Trop. Med., 6:139. Also correction by Thompstone, Ibid. 6:160.

Two males and two females collected by Thompstone in Opobo, Nigeria. Description scanty; purely anatomical.

PACE, A.

I867. Sopra un nuovo nematodo. Giorn. sci. nat. ed econom., 2.

Worm taken from tumor of upper eyelid of boy; named $F$. palpebralis (nec Wilson, 1844). Not $F$. loa, perhaps $F$. conjunctivae Addario (1885, q.v.).

Penel, R.

1904. Les filaires du sang de l'homme. CR. sect. méd. et hyg. colonial., Paris, 199-217.

The autopsy of a Congo negro in Paris showed many adult $F . l o a$ in the superficial connective tissue of the appendages, none elsewhere. $F$, loa appears in the eye only when young and äctive. It lives later elsewhere and causes transitory unexplained troubles or more often none at all.

I905. Les filaires du sang de l'homme. Arch. Parasitol,, $9: 187-204$.

Reprint of Penel, R., 1904.

\section{Piccirilli, - -}

1879. Del elmintiasi oftalmica. L'Independente, I879:425-30.

Not seen; cited after Parona, Elmintologia Italiana. Small structures in anterior chamber; probably not worms.

Pick, L.

1905. DDemonstration einer durch Operation gewonnenen Filaria loa.] Dtsch. med. Woch., 31:1 I72.

Specimen taken from tunder conjunctiva in February, 1905. Host lived in Kamerun 1897-98, since then in Germany. No intimation of its presence until day before its removal. "The worm is an intestinal (sic!) parasite."

Pigafetra, Filippo.

I598. Vera descriptio regni africani, quod tam ab incolis quam

Lusitanis Congus appellatur. Francoforti VV. Richter, \& Th. \& Io. de Bry. 
Falsely cited by various authors as furnishing evidence of the occurrence of $F$. loa in Africa in the sixteenth century. (Cf. Ward, 1905.)

Plehn, Fr.

r898. Die Kamerun-Küste. Studien zur Klimatologie, Physiologie und Pathologie in den Tropen. Berlin, $8^{\circ}, 3^{6} 3$ pp., I chart, 47 text figs.

Observed three cases in Kamerun negroes, a fourth in an English official was not seen personally. According to natives the worm occurs in the eye of goats and sheep also. Attributes to F. loa "probably" also certain fugitive swellings and dermal inflammations about the size of a silver dollar.

Primrose, A.

I903. Filariasis in man cured by removal of the adult worms in all operation for lymph scrotum. Brit. Med. Jour., I903, 2 : $262-65$.

Records two cases of $F$. loa in Canada. No examination of blood for embryos.

1905. Idem. Canad. Pract. \& Rev., Toronto, 30:135-46.

Reprint of Primrose, 1903.

Proux, W. T.

1902. Filariasis in Sierra Leone. British Med. Jour., 2:87981. Rev. CB. Bakt. u. Par., $32 \mathrm{R}: 528$.

One case $F$. loa in a European, two worms removed, one from eyelid, other from loose skin of penis; patient had lived in Congo, blood swarming with embryo nematodes. 'First case in Sierra Leone, probably introduced.

QUADRI, A.

1858. (Note dans procès-verbaux de la deuxième section, séance du 15 septembre, pp. I 53-57, 3 figs.) Congrès d'Ophthal. de Bruxelles, Compte-rendus (Session de I857). Paris.

Filaria in vitreous body determined by ophthalmoscope; pronounced by later critics nothing more than persistent hyaloid artery, although confirmed by Della Chiaje.

Raililiet, A.

I893. Traité de zoologie médicale et agricole. 2me éd. Paris. ire fasicule.

Brief (p. 529); no new cases or facts. 
RAYER, $P$.

r843. Note additionelle sur les vers observés dans l'oeil ou dans l'orbite des animaux vertébrés. Archives méd. comparée, I : I I3-54.

Cites thirteen cases in all, the last of which concerns a cysticercus, some others are uncertain also.

Robertson, D. Argyll.

I894. Filaria loa. Medical Societies. (Ophthalmological Society. Meeting Oct. I8, I894.) Lancet, London, I894, 2 :977-78. Also Br. Med. Jour., 2 :920-2I.

Woman lived eight years in Old Calabar; worm noted in both eyes, removed eight months after return; cites other cases. Discussion by Manson notes resemblance between embryos of $F, l o a$ and $F$. diurna.

1894a. Case of Filaria loa in which the Parasite was Removed from under the Conjunctiva. Ophth. Rev., 13:329-3I. Rev. CB. Augenheilk., 1894:388.

Same case as 1894 . Both preliminary to Robertson, 1895b.

I 894 b. Cas de Filaria loa souis-conjonctivale. Annales d'oculist., I $12: 336$. ,

Literal translation of Robertson 1894a.

1895. A Case of Filaria.loa. Ophth. Rev., London, 14:93-94.

Removal of second specimen from same patient as noted in Robertson, 1894. Preliminary to Robertson, 1895b.

1895a. [Translation of Proc. Ophth. Soc. United Kingdom, March 14, I895.] Annales d'oculist., I I $3: 277-78$.

Translation of Robertson, 1895.

I $89^{\circ}$ b. Case of Filaria loa in which the Parasite was Removed from under the Conjunctiva. Trans. Ophth. Soc, London, $15: 137-67 ; 2$ pl. Rev. in Arch. Ophth., N. Y., $25: 421$.

Records four new cases, reviews old cases, adds note on female $F$. loa from right upper eyelid of same patient and report by Manson on structure of these specimens and Logan's.

1895c. Demonstration einer Filaria loa. Ber. Versammel. ophth. Ges., Heidelberg, 24:238. (Pub. at Stuttgart.)

Brief description and exhibit of specimens (two females and one male) from England. 
1897. Filaria loa [Ophthalmological Society.] Lancet, London, I897, I :I744.

Return of his patient to Old Calabar two years previous marked by immediate recurrence of her symptoms in aggravated form. Itching behind the eyes and swellings in the arms were most prominent and said to be almost universal in Gaboon. Return to England, but no relief. No embryos in blood, excreta, saliva, or mucus.

1897a. [Quoted on $F$. loa in I.ondon letter of July 2.] Med. Rec., N. Y., 52 :I04.

Brief abstract of Robertson, 1897.

I904. Letter quoted by Habershon, 1904 (q.v.).

Roth, FeLIX.

I896. Filaria loa. Lancet, London, $\mathrm{I}: 764$. Rev. in CB. Bakt. u. Par., 19:790-91.

Native girl on Niger coast, West Africa; worm not extracted. Other cases in same village. This specimen in eyelid, wandered across to other eyelid.

\section{Roulin, - -}

I832. Dragonneau. Arch. gén. de méd., 30:573.

This reference is given as above by Blanchard (1899) and others. Guyon. (1864) says it is wrongly attributed to ClotBey (q.v.) in the review where it was published. I can find no trace of a similar article by Roulin in this volume or elsewhere.

Roux, Fernand.

I888. Traité pratique des maladies des pays chauds. Paris, G. Steinhail, 3 vols.

Brief ( $3: 552)$, no new cases, gives $F$. lachrymalis as synonym! SAMBon, L. W.

1902. Remarks on the Individuality of Filaria diurna. Jour. Trop. Med., 5:38I-84.

Careful critique of Annett, Dutton, and Elliott's view of the identity of $F$. diturna and $F$. Bancrofti. Some difficulties due to mixed infections, others to incomplete evidence. No other embryo in West Africa which can belong to $F$. loa. Known facts accord with probable life history as taken from other species of filaria. 
1903. [Continuation of Ig02.] Jour. Trop. Med., $6: 26$.

Annett, Dutton, and Elliott's suggestion of a diurnal mosquito as host for $F$. diurna fatal to their theory of identity. Manson's suggestion of Mangrove flies more probable; certainly to be found among Tabanidae.

Santos, Christovió José dos.

I833. Case recorded in Sigaud, I844 (q.v.).

Santos-Fernandez, D. J.

I879. Filaria en al cuerpo vitreo. Cron. méd-quir. de la Habana, $5: 43^{6}-3^{8}$.

Not found; cited from Surgeon General's Catalog. "Twice found nematodes in vitreous humor" (Yarr, 1899).

I882. Cron. méd.-quir. Habana, 8: I I6.

Cited thus by Kraemer, 1899. The page given is incorrect, and I could not find any such paper or note in volume 8 .

Scheube, B.

1900. Die Krankheiten der warmen Länder. Jena, G. Fischer, 2d Aufl., 66r pp., 7 pl., 5 charts, 30 text figs.

Says $F$. loa (p. 492) can be in anterior chamber, and is probable cause of Calabar swellings.

1903. The Diseases of Warm Countries. Translated from the German by Pauline Falcke. Edited by James Cantlie. London, John Bale, Sons, 2d ed., 594 pp., 7 and I2 pl., 58 text figs.

$F$. loa (p. 441); says Manson has relinquished the view that

$F$. diurna is the larval form corresponding to this adult.

ScriöLER, - -

I875. [Demonstration.] Berlin. klin. Woch., I2:682. ( $13: 8$, discussion.)

Before Berlin Medical Society; woman with living nematode 12-15 mm. long spirally rolled and actively moving in lens. Virchow examined carefully. Interpreted by later critics as persistent hyaloid artery.

Sermon, G.,

I872. Case of Filaria oculi occurring in practice; operation and recovery. Canada Med. Rec., Montreal, I :I73.

The patient was a bay mare! The species certainly not $F$. loa. 
Stebold, C. 'I'r. von.

I839. Bericht über die Leistungen im Gebiet des Helmin- , thologje während des Jahres 1838. Archiv f. Naturg., I839, $2: 152$.

Brief reference to case of Guyot [Guyon?]; also to Clot. Moniez (1896) says that both names are wrong in this review.

Sigaud, J.-F.-X.

I844. Du climat et des maladies du Brésil ou statistique médicale de cet empire. Paris, $8^{\circ}$.

A Filaria (p. 135) in the orbit, behind the sclerotic, in a negress of Rio Janeiro. May have been a Guinea worm, and not a Loa.

Stellwag von Carion, Cari.

1858. Die Ophthalmologie. Erlangen, 2 vols.

Quoted by Kraemer, 1889, as a case of Guinea worm in the orbit; no.cases or data given, account very brief; more probably referable to $F$. loa.

Stossich, M.

I897. Filarie e Spiroptere. Lavoro monografico. Boll. Soc. Adriat., I8:I3-r62. Rev. in Zool. Centr., 5 :124; Jour. Roy. Mic. Soc., 'I898:63.

Brief taxonomic description (p. 21); few citations.

Supino, F.

1900. Sopra una Filaria dell'occhio umano. Rend. Acc. Lincei, (5) $9: 85-9$ I, 3 figs.

Not $F$. loa. Specimen from Grassi, same as Addario's (1885) F. conjunctivae. ,

Terrin, L.

I884. Étude sur le cysticerque de l'oeil. Thèse. Fac. de méd., Montpellier, no. 78 .

F. loa (pp. 46-48) as Obs. V., par M. Lota.

Texier, - - -

1903. (Cited by Penel, r904.)

Found $F$. diurna in a subject which appeared to have been a host for F. loa. 
Thompstone; S. W.

I899. Calabar Swellings. [Letter with editorial additions.] Jour. Trop. Med., 2 :89-9o.

Discusses fugitive swellings at Old Calabar. Editor notes similar trouble in Robertson's patient with $F$. loa, but only "since her return home."

TruCy, CH.

1873. Remarques sur la Filaire de Médine et en particulier sur son traitment. Thèse (Fac. de méd.) Montpellier, No. 22, $4^{\circ}, 42$ pp.

Regards F. loa as identical (p. 8) with Guinea worm and cites one case by Maurel in Gaboon who extracted worm in 1868. Complete recovery.

Turnbull, C. S.

1878. Filaria in the Eye. Med. and Surg. Reporter, Phila., $39: 35$ I -55 .

Only brief references to previous cases of $F$. loa. Case observed was in eye of horse.

WARD, H. B.

1902. A Record of the Occurrence of Filaria loa, a Human Parasite new to the United States. Science, n. s. I6:350.

Brief announcement of the specimen of Milroy and of the reading of this paper. No data given.

1903. Nematoda. Wood's Reference Handbook of Medical

Sciences. Rev. Ed., 6:205-25.

Reference (p. 211) to case of Milroy and figure of posterior end of this specimen; spicules incorrectly reproduced.

1905. The Farliest Record of Filaria loa. Zool. Annalen, $1: 376-84$, I fig.

Shows that the illustration cited from records of early voyages as evidence of the occurrence of $F$. loa is a fancy picture and can not be interpreted in the manner suggested.

1905a. Studies on Human Parasites in North America. 'I. Filaria loa. Studies from the Znological Laboratory No. 63. University Studies Vol. V, p. 27 I.

The present paper. 
Wilson, F. M.

1890. Specimens of Filaria oculi humani, Trans. Amer. Ophthalm. Soc., Hartford, $5: 727-29$.

Incompletely cited by Blanchard, 1899; missionary at Benita (Gaboon) W. Africa says at intervals all natives feel worms in different parts, extract them from eye only; she had one removed at Basel (Switzerland), February, 1889, from left upper eyelid; one in Bridgeport, Conn., November, 1899, from right upper eyelid; one in Clifton Springs, N. Y., February, 1890, from beneath skin of back; and broken one July, 1890, from right upper eyelid. "So far as I have been able to obtain the evidence from the missionaries themselves, these filariae are more common in the cellular tissue than in the eyeball. From the literature we should infer the opposite."

WURTZ, R.

Igo4. Presentation d'une Filaria loa. Soc. méd. hyg. trop., séance, 20 jan.

Not seen; cited after Wurtz et Clerc, 1905.

Wurtz, R., et Clerc, A.

1904. Éosinophilie intense provoquée par le Filaria loa. CR. Soc. Biol., Paris, 55:1704-5.

Young French girl in Congo with Calabar swellings and $F$. loa had no embryos in blood, but intense eosinophilia; latter known for genus Filaria, but not noted heretofore for $F$. loa.

1905. Nouvelle observation de Filaria loa. Considerations sur 1'hematologie des filarioses. Arch. méd. exp., Paris, I $7: 260-66$.

Sane patient as above returned to France in June, 1903. In January, 1904, worm extracted from eye. Eosinophilia-somewhat reduced, but returned later. Extreme symptoms and continuance indicate that several,parasites are present. Discussion of parasite, Calabar swellings, and eosinophilia in helminthiasis.

YARR, M. T.

I899. The Filariae of the Eye. Jour. Trop. Med., I :I76-79.

Native name of Loa means simply "worm." Good review of previous knowledge. No new cases. Records the conjecture of Manson that the cases from the West Indies, also that of Barkan (1876) concern the adult of F. Demarquaii, and not F. loa. 
Zieman, Hans.

1905. Beitrag zur Filariakrankheit der Merschen und Tiere in den Tropen. Dtsch. med. Woch., 3I :420-24.

$F$. loa (p. 421) increasing in that region. Sees in $F$. perstans in blood the embryos of $F$. loa and unites $F$. diurna to $F$. Bancrofti. Not every case with $F$. perstans in blood and Calabar swellings has had $F$. loa in eye. Distribution of microfilariae in body very irregular. Data on other species, therapy, etc. 